\title{
Systematics and distribution of cumaceans collected during BENTART-95 cruise around South Shetland Islands (Antarctica)*
}

\author{
JORDI CORBERA
}

Carrer Gran 90. Argentona 08310. Spain. E-mail: corbera@sct.ictnet.es

\begin{abstract}
SUMMARY: During the BENTART-95 cruise, 24 stations around the South Shetland Islands and Trinity Island, ranging from 45 to $649 \mathrm{~m}$ bottom depth, were sampled using a Macer-GIROQ sledge. Alltogether, 1236 specimens of cumaceans belonging to 25 species were captured. Four of them are new species named Cumella emergens, Procampylaspis halei, Campylaspis heterotuberculata and Leucon (Crymoleucon) costatus. Distribution of cumaceans in this area is depth-dependent and the highest diversity was observed at the deeper station. A total of 68 species have been recorded from Antarctic and Subantarctic waters, the greatest part (47 species) were found between 50 and $300 \mathrm{~m}$ depth; only 3 species inhabit below $2,500 \mathrm{~m}$ depth. Antarctic cumacean fauna shows a high degree of endemism at a specific level ( $91 \%)$, however, only one genus of 19 is endemic. By regions, the Kerguelen Islands have the highest percentage of endemic species (56\%). Antarctic cumaceans do not seem to have a common origin, some species could have colonized Antarctica through Scotia Arc (as the genus Campylaspis) or emerged from deep-sea while others may be radiated from Antarctica to lower latitudes (as the species of subgenus (rymoleucon).
\end{abstract}

Key words: Cumacea, swimming activity, suprabentos, systematics, distribution, biogeography, Antarctica.

\section{INTRODUCTION}

Cumaceans are mainly marine benthic peracarid crustaceans inhabiting all oceans from the intertidal zone to the deepest bottoms (Jones 1969). Although cumaceans can penetrate into the sediment (Fage, 1951) they are an important component of suprabenthic communities (Mees and Jones, 1997). Some littoral species undertake nictemeral migrations (Macquart-Moulin, 1991) and recently, vertical movements have also been observed for a few deep sea species (Cartes and Sorbe, 1997). This behavioural pattern would support the presumed contribution of cumaceans, as other suprabenthic crustaceans

\footnotetext{
*Received March 11, 1999. Accepted November 12, 1999.
}

(Brandt 1993, 1995), to the bioturbation and resuspension in the benthic ecosystem. Moreover cumaceans are a food source for fishes (Kurian and Radhadevi, 1983) and other macrobenthic invertebrates (Cartes, 1993).

In Antarctic waters, studies on cumaceans are focused mainly on systematics. Most of the expeditions sampled with dredges (Lomakina, 1968; Ledoyer, 1974, 1977; Mühlenhardt-Siegel, 1994; Blazewicz and Jazdzewski, 1995), trawls (Hale, 1937; Jones, 1971; Gamô, 1987; Ledoyer, 1993) and box-corer (Ledoyer, 1993). These gears probably do not sample efficiently on cumaceans (Jones and Sanders, 1972) due to the small size and low density of these crustaceans. Significant differences are observed in composition and density of peracarids 
crustaceans assemblages from the English Channel, which have been sampled with different tow gears (Smith-McIntyre grab and Macer-GIROQ sledge; Dauvin and Zouhiri, 1996). No data on cumaceans sampled with a suprabenthic sled in the Antarctica have been published up to now, however, Siegel and Mühlenhardt-Siegel (1988) reported the use of a Beyer's sled in Antarctic Peninsula region.

Ledoyer (1993) lists 56 species of cumaceans from the Antarctic region, two of them show a wide distribution, 19 are subantarctic species (including 3 from the Magellan region), 13 have Antarctic and subantarctic distribution and 23 are high Antarctic species. However, Ledoyer (1993) did not include the eight species described in his work, and later Roccatagliata and Heard (1992) and MühlenhardtSiegel $(1994,1996)$ added three new species.

The present study deals with the faunistical composition and distribution of cumaceans that occur near the South Shetland Islands and it summarizes the present knowledge on both bathymetric and geographic distribution of Antarctic cumaceans.

\section{MATERIAL AND METHODS}

Twenty-four stations located around the Livingston Island, the Deception Island and the Bransfield Strait, at depths ranging from 45 to $650 \mathrm{~m}$, were sampled using a modified version (Cartes et al., 1994) of the Macer-GIROQ sled (Brunel et al., 1978; Dauvin and Lorgeré, 1989) during the BENTART-95 cruise. This cruise was carried out from 16 January to 4 February 1995 on board of the RV Hespérides (see San Vicente et al., 1997 for a detailed characteristics of sampling and preliminary observations on suprabenthic assemblages).

The sled used was equipped with an openingclosing system and with three superposed nets 0.5 $\mathrm{mm}$ mesh size with a rectangular opening of $40 \times 80$ $\mathrm{cm}$ that sample in three water layers: $10-50 \mathrm{~cm}$ (net 1), $55-95 \mathrm{~cm}$ (net 2) and 100-140 cm (net 3) above the sea floor.

The material was sorted with a dissecting stereomicroscope, after fixation in neutral formaline $(10 \%)$ and later being transferred into ethanol (70\%). Only the new species and those which showed a special taxonomic importance were studied in the systematic account. Type material and a reference collection was deposited in the cumacean collection of the Institut de Ciències del Mar (ICM) of Barcelona. Type material of two Antarctic species of the genus
Leucon [Leucon vanhoeffeni Zimmer, 1907 paratypes (5 especimens) MNB no 18342; Obsevatory Bay, Kerguelen Island; and Leucon kerguelensis Zimmer 1908 holotype MNB no 13362; Gazellehafen, St. 160 Deutsche Tiefsee-Expedition, Kerguelen] deposited in the Museum für Naturkunde der Humboldt-Universität zu Berlin(MNB) were studied.

\section{Data analysis}

Abundance of species was expressed as the number of individuals. A diversity index was calculated using the formula of Shannon-Waever:

$$
\mathrm{H}=-\sum \mathrm{p}_{\mathrm{i}} \log _{2} \mathrm{p}_{\mathrm{i}}
$$

An index of swimming activity (Brunel, 1972; Saint-Marie and Brunel, 1985) was calculated for the more abundant species using the following formula:

$$
\begin{aligned}
& \mathrm{K}_{1}=\mathrm{N}_{2} / \mathrm{N}_{\mathrm{t}} \\
& \mathrm{K}_{2}=\mathrm{N}_{3} / \mathrm{N}_{\mathrm{t}}
\end{aligned}
$$

where $\mathrm{N}_{2}$ and $\mathrm{N}_{3}$ are the number of individuals collected in $55-95 \mathrm{~cm}$ and $100-140 \mathrm{~cm}$ water layers above the sea floor respectively and $\mathrm{N}_{t}$ is the cumulative number of individuals from three water layers sampled by the sled.

Cumacean assemblages were identified on the basis of species composition of samples using the cluster analysis (Jaccard's similarity coefficient and UPGMA aggregation algorithm). A Principal Component Analysis (PCA) was performed using a

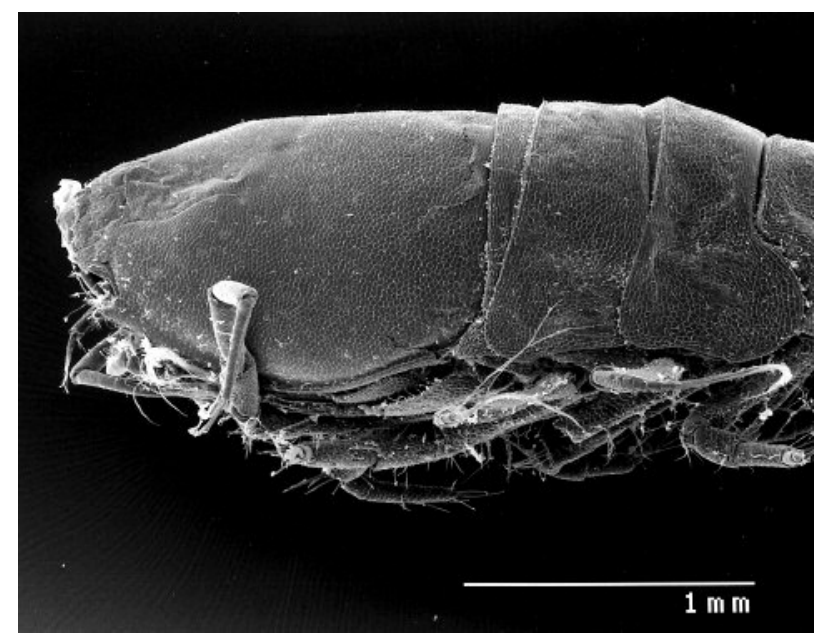

FIG. 1. - Vaunthompsonia laevifrons Gamô 1987, SEM microphotograph of carapace in lateral view. 


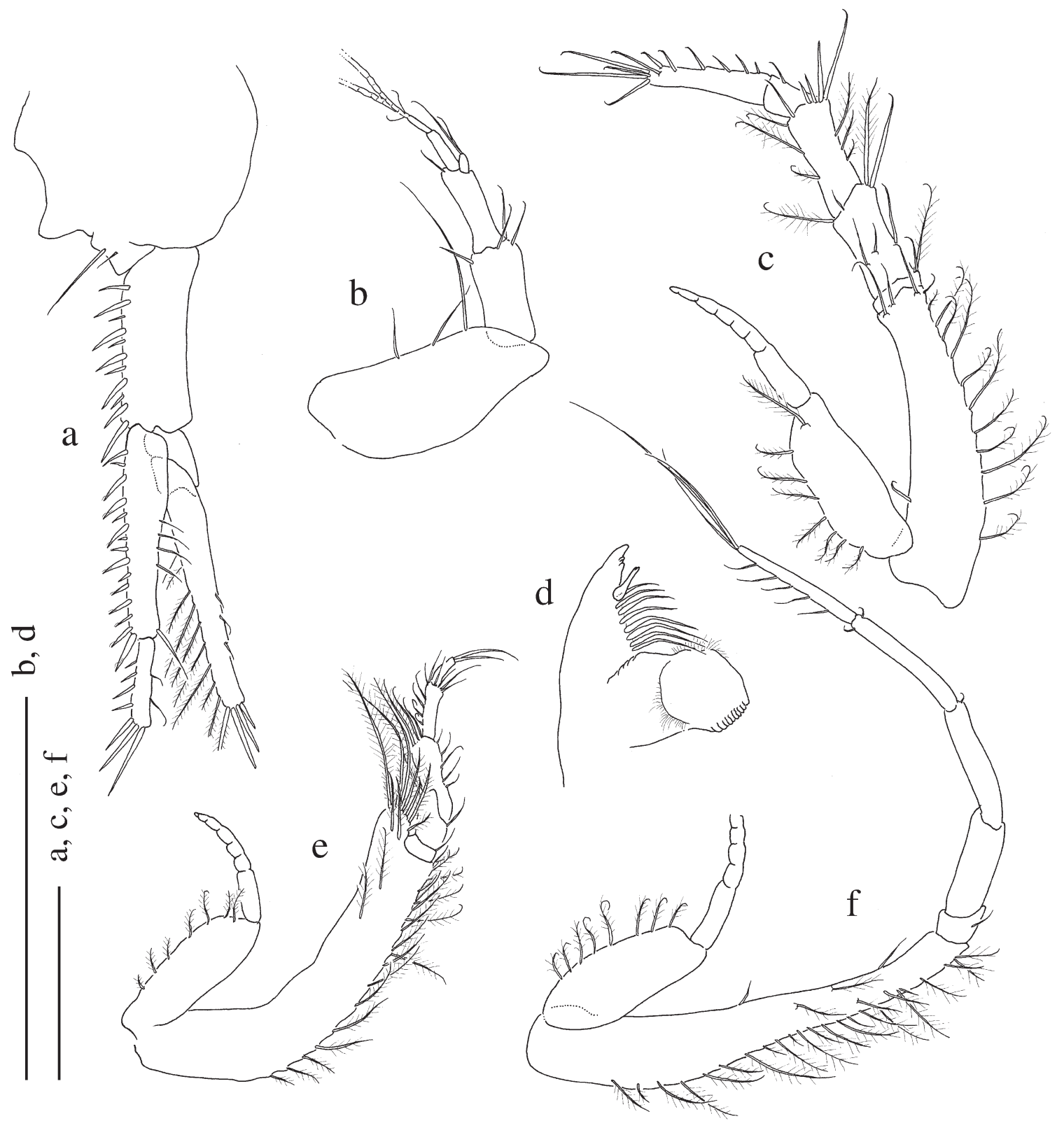

FIG. 2. - Vaunthompsonia laevifrons Gamô 1987, adult female; a) uropod; b) first antenna; c) second pereopod; d) mandible; e) third maxilliped; f) first pereopod. Scale bar $0.5 \mathrm{~mm}$.

transformed abundance matrix comprising the most frequently occurring species to determine the role of environmental parameters on the distribution of cumaceans.

\section{RESULTS}

\section{Systematics}

Order CUMACEA

Family BODOTRIIDAE Subfamily Vaunthompsoniinae
Vaunthompsonia laevifrons Gamô 1987

(Fig. 1, 2)

Vaunthompsonia laevifrons: Gamô 1987, p. 147-149, fig. 2. Ledoyer 1993, p. 1052-1053, fig. 2B.

Material examined: BENTART-95 cruise sta. 3: 6 preadult $q$,+ 3

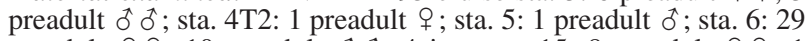
preadult $q+q, 10$ preadult $\delta \hat{\delta}, 4$ jov.; sta 15: 8 preadult $q+q, 1$

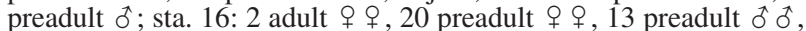
28 jov.; sta. 17: 1 preadult $\varphi$; sta. 19: 3 preadult $\uparrow+, 2$ jov.; sta. 25T1, 1 preadult + ; sta. 25T2, 2 preadult $q$ $~+$; sta. $28: 2$ jov.; sta.

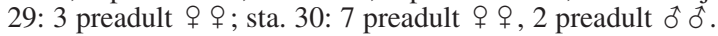

Description: Ovigerous female $6.75 \mathrm{~mm}$ total length (from the tip of pseudorostrum to the end of 
last abdominal somite), carapace (1.5 mm length) (Fig. 1) 1.7 times as long as deep and longer than the four anterior pedigerous somites. Anterolateral margin of pseudorostral lobes with 2-3 small teeth, pseudorostrum not meeting in front of the eyelobe which is rounded and without spines. Antennal notch excavated, anterolateral angle acute and lower margin serrated. Last abdominal somite produced backwards between uropods with one pair of long terminal setae and another very small one.

Peduncle of first antenna (Fig. 2b) three-segmented, first article longer than the following two articles; main flagellum with two aesthetascs. Mandible (Fig. 2d) with eight setae between the incisive and molar process. Basis of third maxilliped (Fig. 2e) longer than the remaining segments together, distal margin slightly produced and with 6-8 long plumose setae. First pereopod (Fig. 2f) with basis shorter than the rest of limb, ischium short, carpus propodus and dactyl long and of similar length. Basis of second pereopod (Fig. 2c) shorter than the rest of limb, ischium very short, merus and carpus of similar length, propodus short and dactyl as long or longer than carpus. Uropod peduncle (Fig. 2a) subequal in length to the last abdominal somite, inner margin with 10-11 spines; rami of same length about 1.5 times as long as peduncle, endopod bi-segmented, proximal article twice as long as distal with 15 spines on inner margin some setae on outer margin; second article with 4 spines on inner margin, 2 setae on outer margin and 3 spines distally.

Remarks: Vaunthompsonia inermis was described from three specimens collected in South Georgia and is distinguished from $V$. meridionalis by the lack of dorsomedian serrated carines. Later, Gamô (1987) described a new species, V. laevifrons, also without dorsomedian serrated carines and based
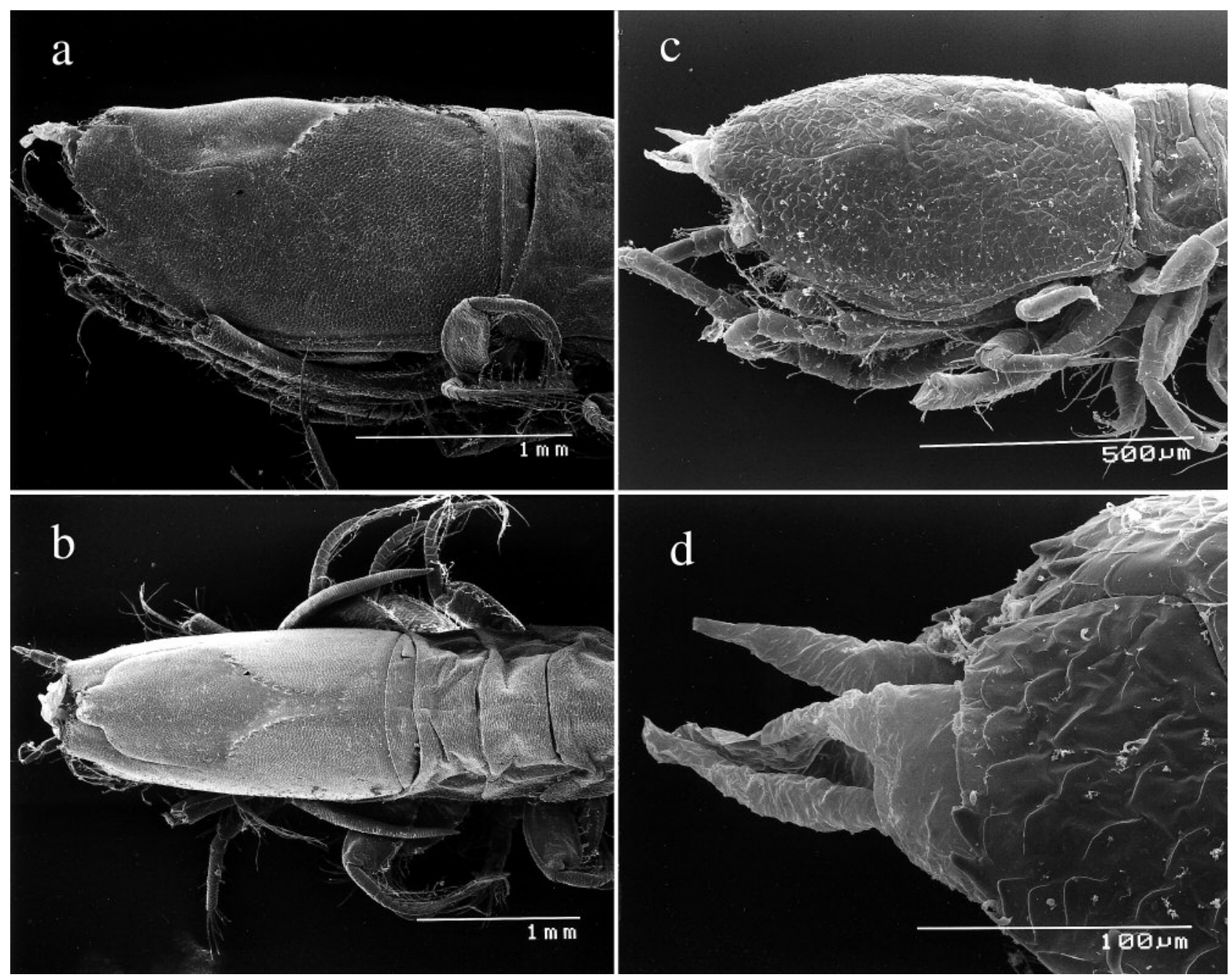

FIG. 3. - Vaunthompsonia meridionalis Sars 1887, SEM microphotograph; a) carapace in lateral view; b) preadult male, carapace in dorsal view; c) manca stage, carapace in lateral view; d) manca stage, anterior tip of carapace showing two small denticles on eyelobe. 
on the relative length of carapace and pereon. However, as Ledoyer (1993) has mentioned, the type material of this species is damaged and this character cannot be considered as valid. This last author attributes the Weddell Sea material to V. laevifrons on the basis of the denticulated upper margin of antennal notch. However, the structure of this margin is not mentioned in the short description of $V$. inermis and it is very difficult to discern in the small figure of Zimmer (1909). Specimens collected during the BENTART cruise are similar to the description of Ledoyer and, have like those from the Weddell Sea a lower number of setae on the hind margin of last pleonite. However, the setation of mandible is not as described by Gamô. Unfortunately, the mandible was not described by Ledoyer (1993). In spite of the mentioned difference in mandible, I prefer to assign the material of the BENTART cruise to V. laevifrons following Ledoyer's criterium.

\section{Vaunthompsonia meridionalis Sars 1887}

\section{(Fig. 3)}

Vaunthompsonia meridionalis Sars 1887, p. 23-25, pl. 2 fig. 1-5. Calman 1905, p. 17. Zimmer 1908, p. 166-168, pl. 38 fig. 34-45, pl. 39 fig. 46-52; Zimmer 1909, p. 4; Zimmer 1920, p. 131. Lomakina 1968, p. 127. Ledoyer 1977, p. 195-196.

Material examined: BENTART-95 sta. 3: 42 preadult $q$ ㅇ, 19

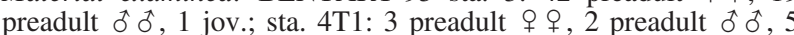
jov.; sta. 9: 2 preadult $q+$, 3 jov.; sta. 10: 1 adult,+ 2 preadult +, 2 jov.; sta 11: 1 preadult $q$; sta. 16,1 ind.; sta. $28: 4$ adult $q+$, 95 preadult $q$,+ 17 preadult $\hat{\text { oे }} \hat{\delta}, 72$ jov.

Remarks: Vaunthompsonia meridionalis is differentiated from the other two Antarctic species of this genus by the two longitudinal dorsomedian serrated carines (Fig. 3a, b). However, this character lacks in manca stage (first postmarsupial stage with pereopod 5 not developed) (Fig. 3c). The detailed study of mancas did not provide differences with manca specimens attributed to $V$. laevifrons, only in some individuals, a pair of small denticles on eyelobe has been observed (Fig. 3d). But this character is very difficult to observe in specimens since mancas, which are generally poorly calcified and frequently damaged. For this reason, mancas was not classified at specific level.

\section{Family NANNASTACIDAE Bate, 1866 Cumella emergens sp. nov.} (Fig. 4)

Type material: Holotype preadult $\widehat{\delta}$ ICM NAN001. Type locality: North of the Livingston Island, BENTART-95 sta. 30, 62 $2^{\circ} 01.45^{\prime}$ 'S $60^{\circ} 25.75^{\prime} \mathrm{W}, 649 \mathrm{~m}$. Paratypes from the same locality: 2 preadult ơ o ICM NAN002
Etymology: Referring to the probable deep-water origin of this Antarctic species.

Description: Preadult male (Fig. 4a) total length $2.3 \mathrm{~mm}$. Carapace 1.6 times as long as deep, slightly tumid posteriorly with 2-3 forward-pointing middorsal teeth on the anterior half. Pseudorostrum short and truncate slightly upturned and siphons moderately long. Eyelobe rounded not elongate, with one spine. Antennal notch wide but little excaved; anterolateral angle marked by a spine followed by serrations. Pereon and pleon unarmed; pleon longer than the carapace and pereon together, last pleonite produced backwards between uropod peduncles.

Basis of first pereopod (Fig. 4d) shorter than the following four segments combined length, ischium and merus short, carpus longer than two preceding segments, propodus shorter than carpus and more than twice as long as dactyl. Second pereopod basis (Fig. 4c) as long as the rest of limb, ischium very short, carpus twice as long as merus and with a long spine on the distal margin, propodus half length of merus, dactyl shorter than carpus and propodus combined length. Uropod peduncle (Fig. 4b) as long as the fifth abdominal somite, endopod 0.8 times as long as peduncle with one spine on inner margin and 2 terminally; exopod tow-segmented shorter tan endopod, second article with a spine on inner margin and 2 distally one of them as longer as exopod.

Remarks: Cumella emergens sp. nov. is anatomically related with deep-water Atlantic species of this genus. Cumella emergens is similar to C. compacta Jones, 1984, C. decipiens Jones, 1984 and C. meridionalis Jones, 1984 for its rounded eyelobe and the moderately upturned pseudorostrum. However it differs from these species by the combined following characters: mid-dorsal teeth only on the anterior half of carapace, anterolateral angle acute and eyelobe with one spine.

Campylaspis heterotuberculata sp. nov.

(Fig. 5)

Type material: Holotype preadult $\$$ ICM NAN-003. Type locality: Deception Island, BENTART-95 sta. 22, $63^{\circ} 03.56^{\prime} \mathrm{S}$ $60^{\circ} 39.54^{\prime} \mathrm{W}, 330 \mathrm{~m}$. Paratype from the same locality: preadult $q$ ICM NAN-004

Etymology: Referring to the different size of carapace tubercles. 

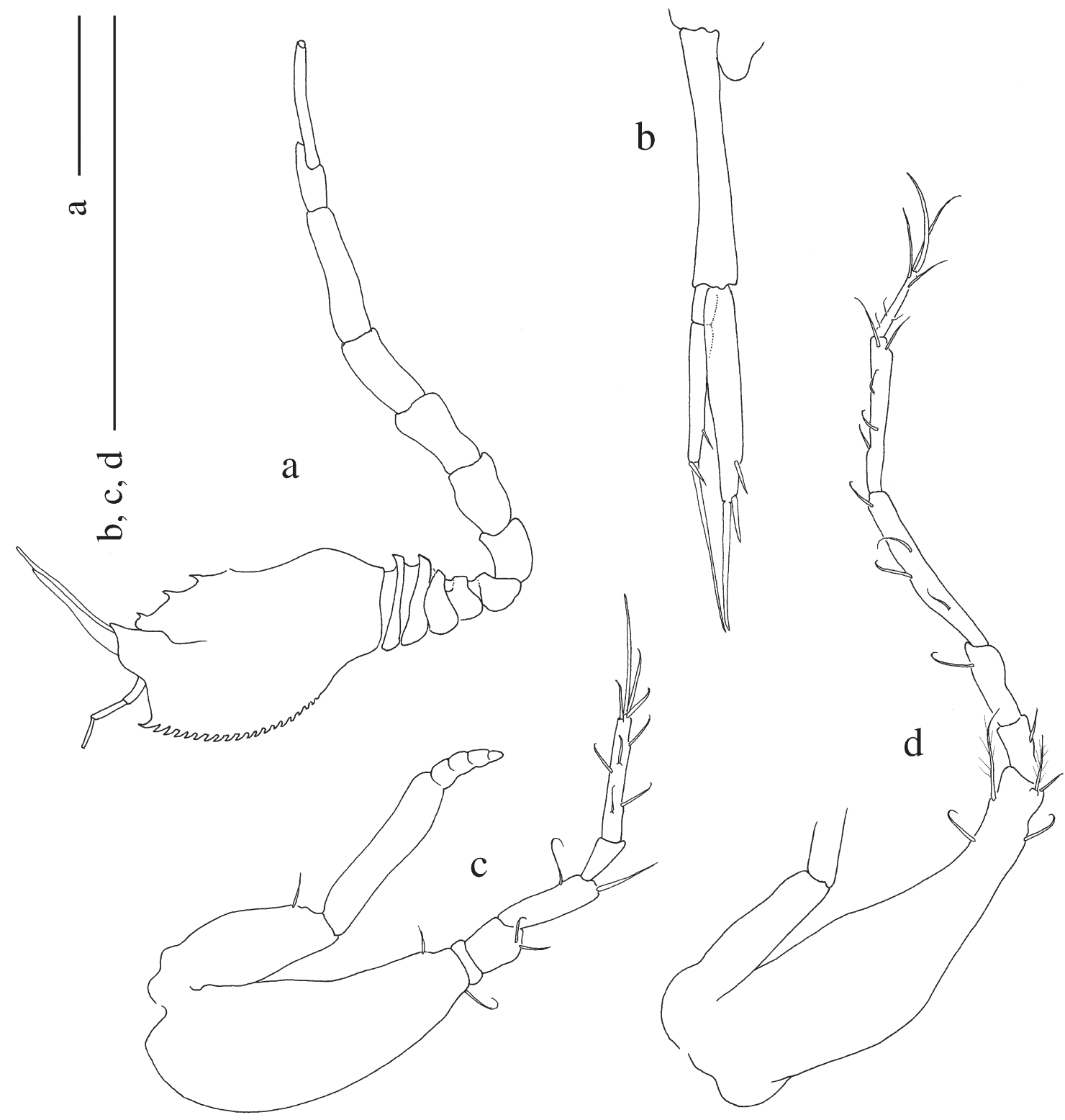

FIG. 4. - Cumella emergens sp. nov. preadult male; a) whole animal in lateral view; b) uropod; c) second pereopod; d) first pereopod. Scale bar $0.5 \mathrm{~mm}$.

Description: Preadult female, $5.1 \mathrm{~mm}$ total length. Carapace (Fig. 5a, b) shorter than half total length, sligthly elevated posteriorly, covered with tubercles of different sizes, the two biggest of them located dorsally in the middle of carapace and turned forwards; pseudorostral lobes short and sligthly upturned; eyelobe rounded, elevated in lateral view; antennal notch distinct and anterolateral angle rounded. Pereon and pleon without tubercles; fifth pleonite without transverse sulcus.

Third maxilliped basis (Fig. 5d) longer than the rest of limb, ischium very short, merus longer than carpus and with distal teeth, outher edge of carpus denticulated, propodus twice as dactyl. Basis of first pereopod (Fig. 5e) wide and shorter than the rest of limb and with distal part of edges denticulated, ischium very short, rest of articles of decreasing length. Basis of second pereopod (Fig. 5f) wide and shorter than de convined length of the following four articles, merus as wide as long, propodus as long as dactyl. Uropod peduncle (Fig. 5c) longer than the last abdominal somite, three times as long as wide and unarmed; endopod one third of peduncle length with 3 small spines on inner edge and 2 distally; exopod two-segmented, shorter than endopod, second segment with 2 small spines distally 


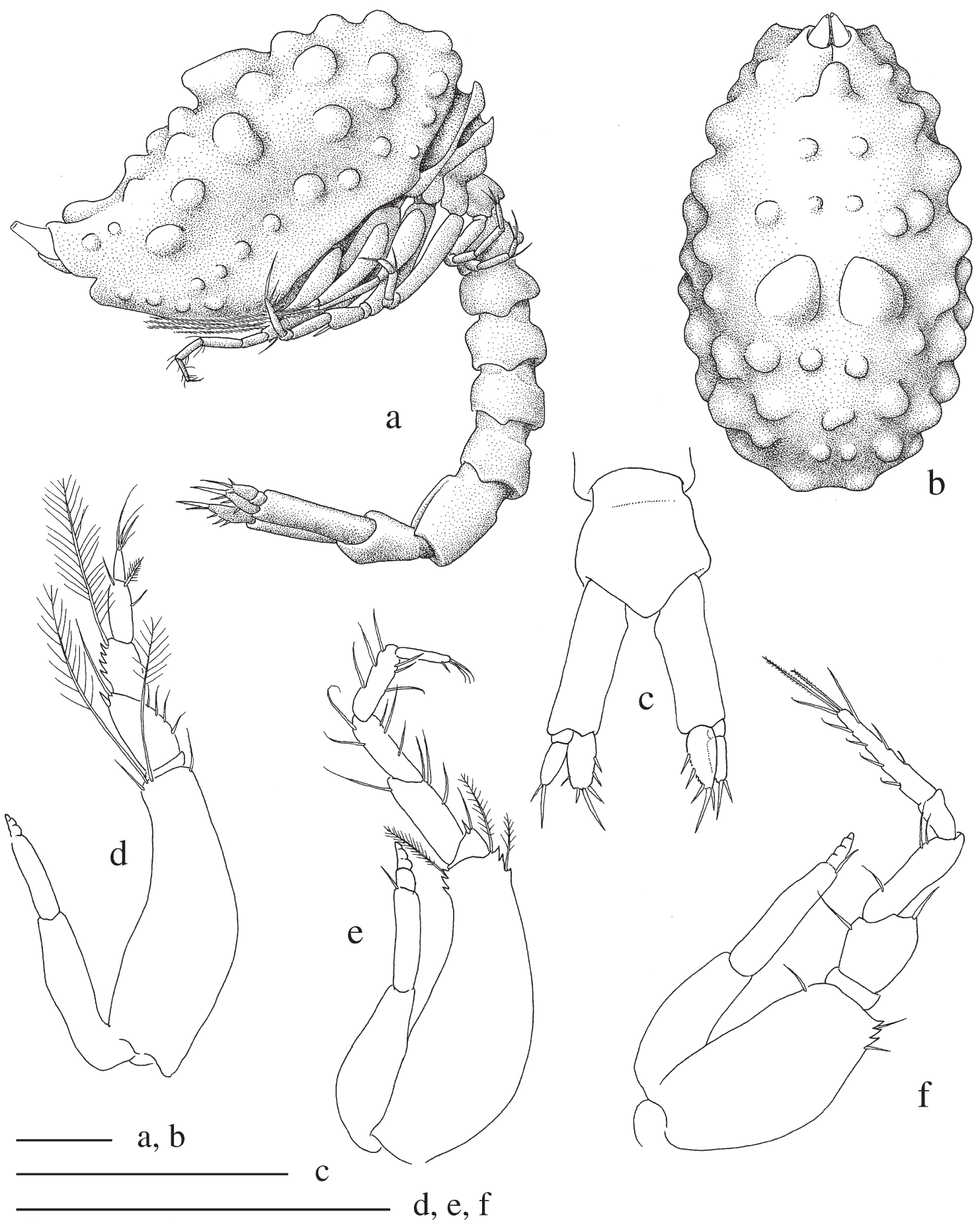

FIG. 5. - Campylaspis heterotuberculata sp. nov. preadult female; a) whole animal in lateral view; b) dorsal view of carapace; c) uropods and last abdominal somite; d) third maxilliped; e) first pereopod; f) second pereopod. Scale bar $0.5 \mathrm{~mm}$.

Remarks: Campylaspis heterotuberculata sp. nov. is closely related with $C$. breviramis Ledoyer, 1993 and C. quadridentata Ledoyer, 1993 specially by the structure of the uropod. However, the shape and distribution of carapace tubercles and the lack of transverse sulcus on the fifth pleonite differ $C$. heterotuberculata from the other two species.

\section{Procampylaspis halei sp. nov.}

(Fig. 6)

Type material: Holotype: adult + ICM NAN-005. Type locality: North of the Livingston Island, BENTART-95 sta. 30, 6201.45'S $60^{\circ} 25.75^{\prime} \mathrm{W}, 649 \mathrm{~m}$. Paratype from the same locality: preadult $q$ ICM NAN-006 


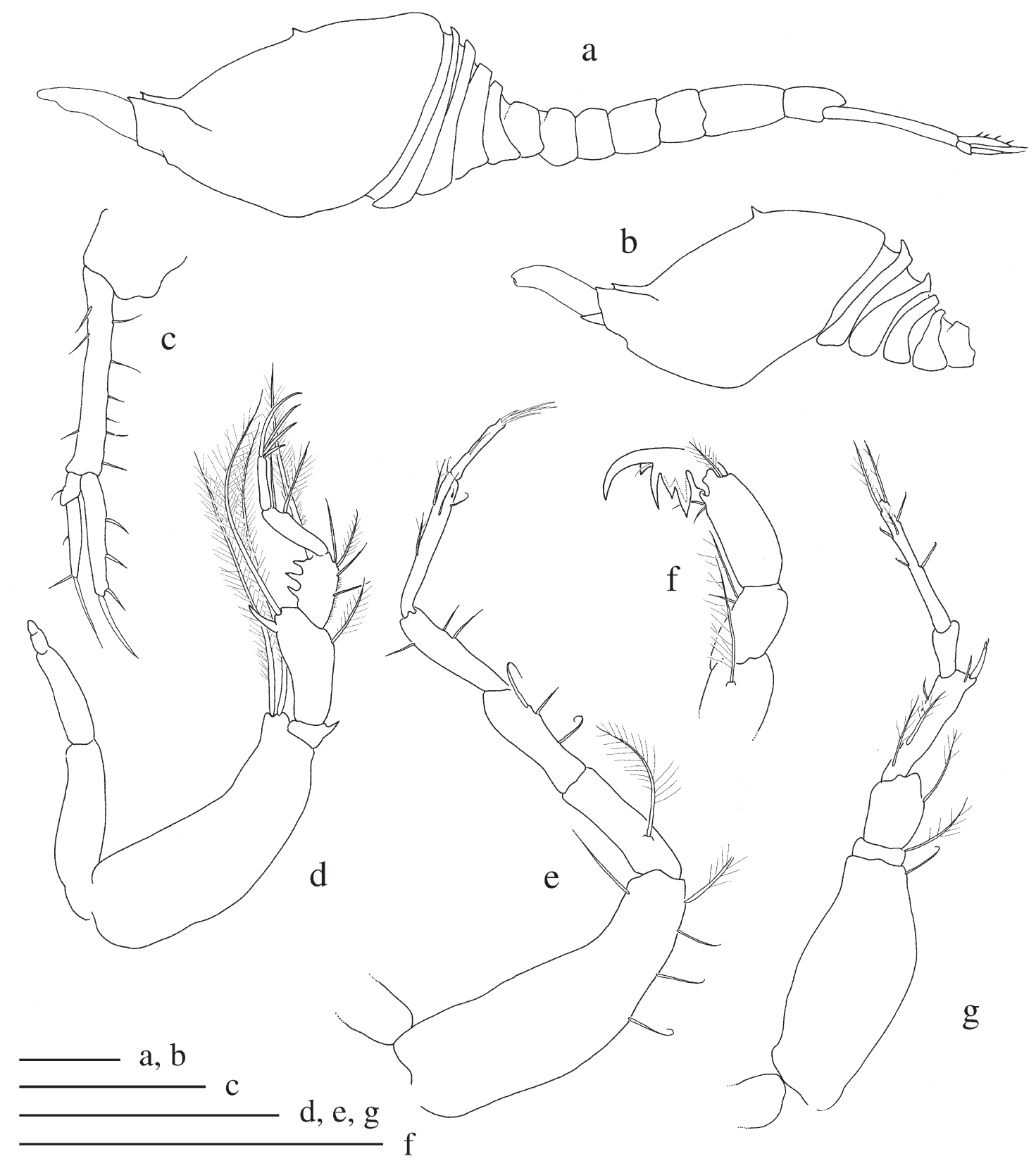

FIG. 6. - Procampylaspis halei sp. nov. adult female (a, d-g) and preadult male (b, c); a) whole animal in lateral view; b) carapace and five free thoracic somites; c) uropod; d) third maxilliped; e) first pereopod; f) last segments of second maxilliped; g) second pereopod. Scale bar $0.5 \mathrm{~mm}$.

Etymology: This species is named in honour of the Australian carcinologist H. M. Hale.

Description: Adult female $3.6 \mathrm{~mm}$ total length. Carapace less than half of total length, sligthly tumid posteriorly and with a single median dorsal spiniform tubercle (Fig. 6a). Eyelobe narrow, longer than half length of pseudorostral lobes and ending by a small teeth. Antennal notch very open and little excavated, anterolateral angle very obtuse.
Dactyl of second maxilliped (Fig. 6f) with tree teeth on inner margin, first of them bifid not deeply cleft, with the proximal part longer than distal part and similar in length to the second teeth. Ischium of the third maxilliped (Fig. 6d) short with an inner tooth, merus widest distally with an outstanding spine on outer margin, carpus outher margin threedentated, inner margin unarmed. Basis of first pereopod (Fig. 6e) shorter than following three articles combined lengths, propodus twice as carpus. Basis of second pereopod (Fig. 6g) longer than following 
three articles together, carpus widest distally with a distal spine and dactyl as long as carpus. Uropod peduncle (Fig. 6c) subequal in length to the last two abdominal somites, with some setae on inner and outer margin; endopod 0.6 times as long as peduncle with 3 spines on inner margin and 1 distally; exopod two-segmented, shorter than endopod; first article with 1 small seta on outer margin, second article with 1 seta on outer margin and 2 distally (longest seta as long as second article).

Remarks: Procampylaspis halei sp. nov. is quite similar to P. sordida Hale, 1945 especially by the mid-dorsal spine of carapace, the relative length of the second pereopod dactyl and the spine of merus of the third maxilliped. However, the proximal teeth of dactyl of the second maxilliped that is bifid and not deeply cleft, together with the carpus armature of the third maxilliped, differ $P$. halei from $P$. sordida.
Family LeUCONIDAE Sars, 1878

Leucon (Crymoleocon) costatus sp. nov.

(Figs. 7-9)

Type material: Holotype adult + ICM LEU-001. Type locality: South of the Livingston Island, BENTART-95 sta. 9, 62³9.73’' $60^{\circ} 39.36^{\prime} \mathrm{W}, 163 \mathrm{~m}$. Paratypes from the same locality: 2 preadult $\widehat{c} \hat{0}$, and 2 preadult $q$ ? ICM LEU-002

Material examined: BENTART-95 sta. 3: 1 adult,+ 13 preadult

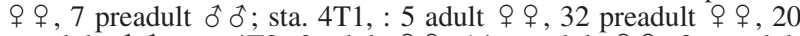

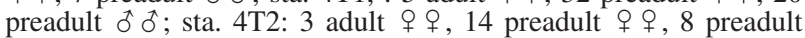

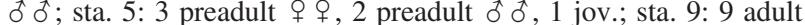

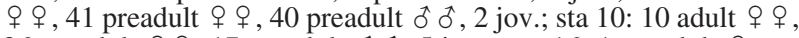

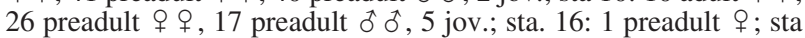
28: 3 adult $q+q, 17$ preadult $q$,+ 5 preadult $\delta \hat{\delta}, 1$ jov.

Etymology: From Latin costa (ridge) referring to the dorsolateral ridge on the carapace.

Description: Adult female $4.2 \mathrm{~mm}$ total length. Carapace (Fig. 7c,d) less than one-third of total length, dorsally serrated with 10 serrations on ante-
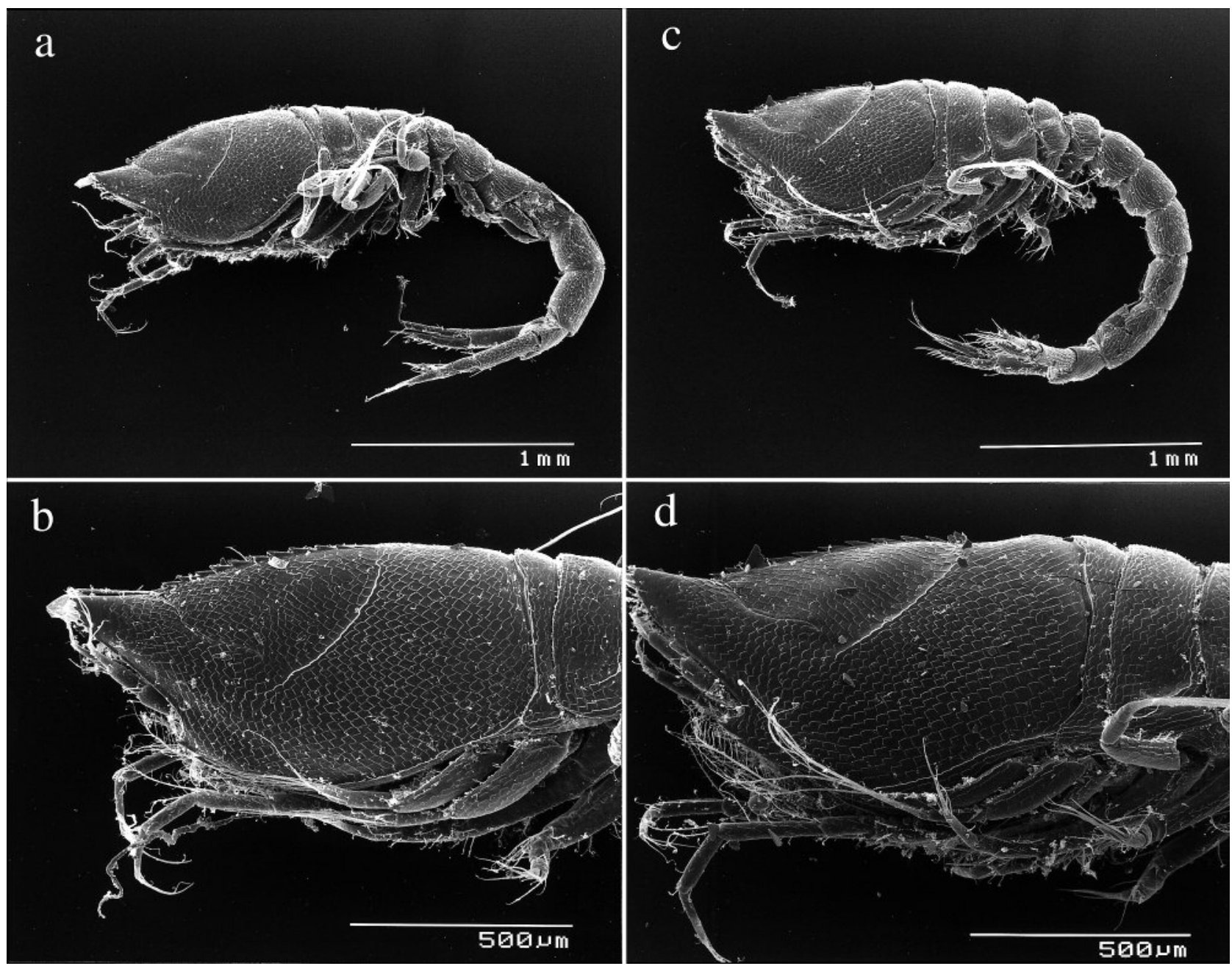

FIG. 7. - Leucon (Crymoleucon) costatus sp. nov. preadult male (a, b) and adult female (c, d); a) whole animal in lateral view; b) lateral view of carapace; c) whole animal in lateral view; d) lateral view of carapace. 


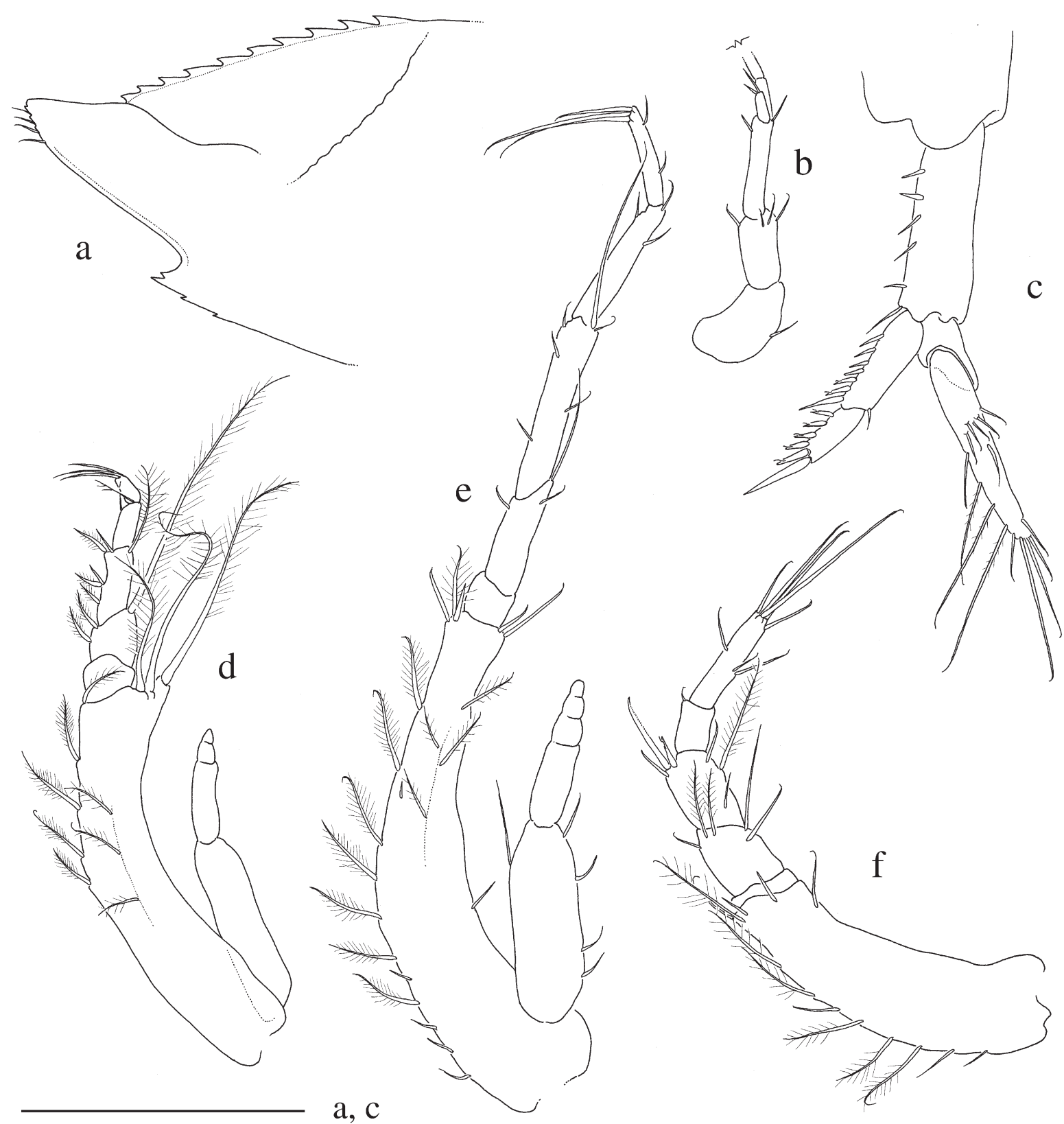

$\mathrm{b}, \mathrm{d}, \mathrm{e}, \mathrm{f}$

FIG. 8. - Leucon (Crymoleucon) costatus sp. nov. adult female; a) anterior half of carapace showing the dorsolateral ridge and the anterolateral angle; b) first antenna; c) uropod; d) third maxilliped; e) first pereopod; f) second pereopod. Scale bar $0.5 \mathrm{~mm}$.

rior half (Fig. 8a); antennal notch deep, anterolateral angle acute, ventral margin with two teeth. Carapace with a dorsolateral slanting ridge.

Antennular peduncle three-segmented (Fig. 8b), last segment 1.25 times as long as second; accessory flagellum longer than half length of basal article of main flagellum. Basis of third maxilliped longer than the rest of limb, distal margin rather laterally extended and bearing three long plumose setae, car- pus also with a long plumose seta, and the last three segments of decreasing length (Fig. 8d). First pereopod (Fig. 8e) with basis longer than the following four segments together and its inner margin with a row of plumose setae; merus shorter than carpus, both with a distal long seta. Basis of second pereopod (Fig. 8f) of similar length than the remaining articles together; ischium very short; dactyl twice of propodus. Peduncle of uropod (Fig. 8c) longer than 


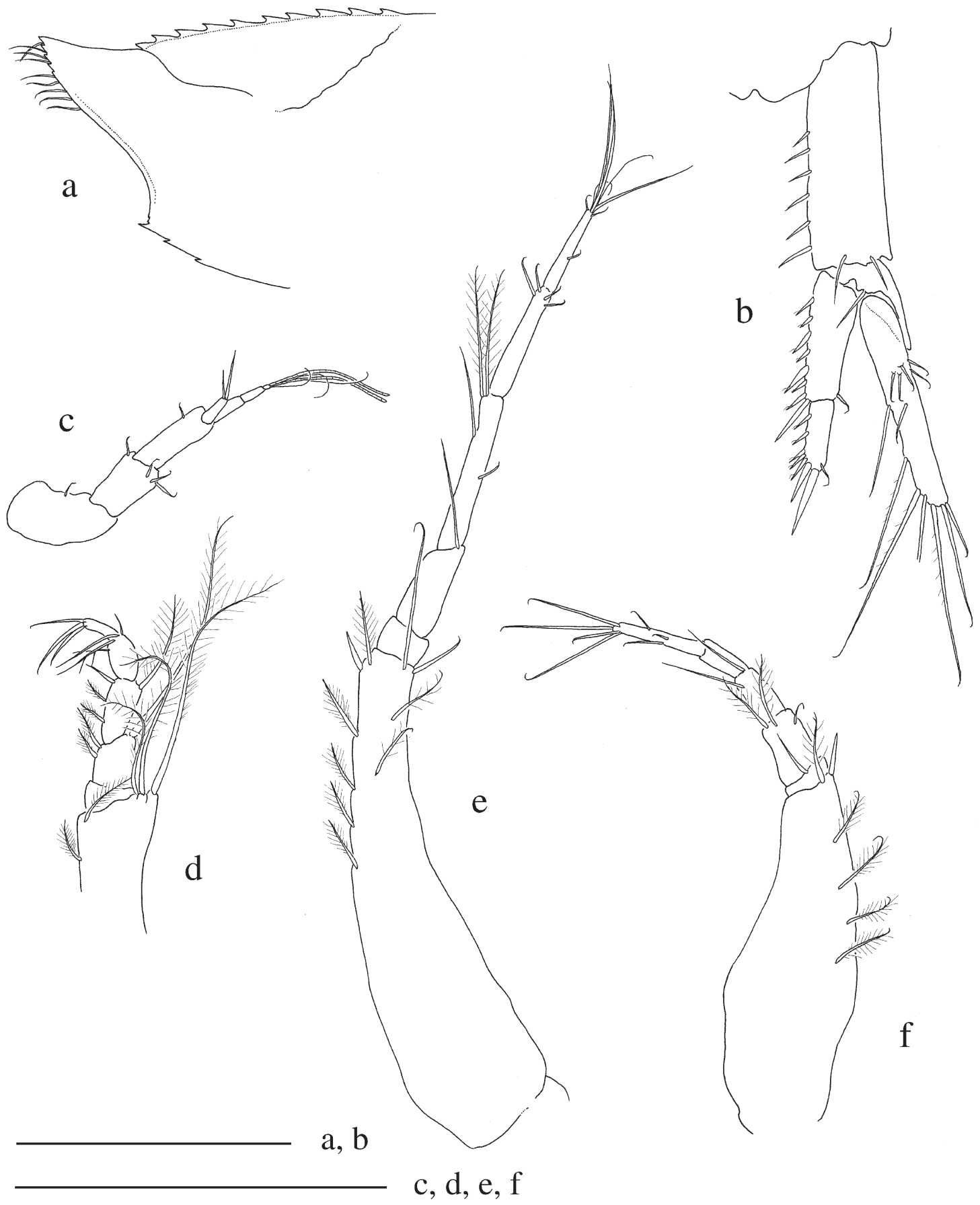

FIG. 9. - Leucon (Crymoleucon) costatus sp. nov. preadult male; a) anterior half of carapace showing the dorsolateral ridge and the anterolateral angle; b) uropod; c) first antenna; d) third maxilliped; e) first pereopod; f) second pereopod. Scale bar 0.5 mm.

the last abdominal somite with 6 small spines on inner margin. Endopod two-segmented, sligthly shorter than peduncle; first article 1.6 times as long as second, with 7 spines on inner margin; second article with 5 spines on inner margin and 1 distally which is long as he second article. Exopod two-segmented, longer than peduncle; second article with some small setae on upper side and long plumose and simple setaeon inner margin and distally.

Preadult male (Fig. 7a, b and 9) is very similar to the adult female but differs by the shape of antennal notch which is very shallow.

Remarks: Leucon costatus sp. nov. is very closely related with L. vanhoeffeni Zimmer, 1907 but it differs by the dorsolateral slanting ridge and the higher 

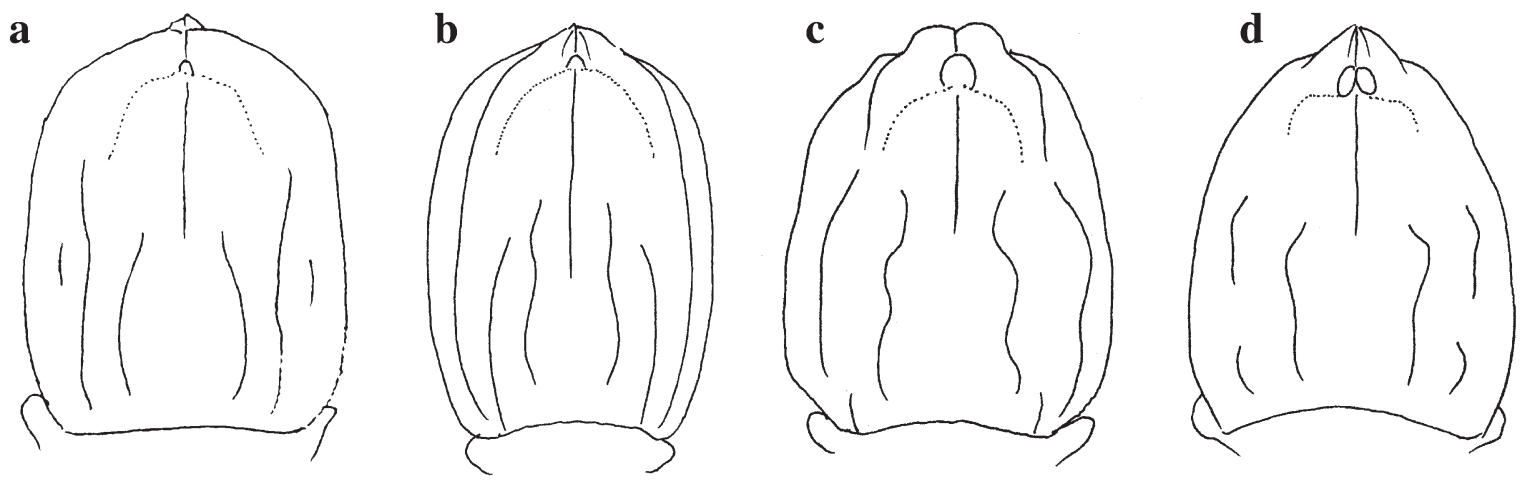

FIG. 10. - Carapace diagrammatic representation of four Paralamprops species found in Antarctic waters showing dorso-lateral ridge distribution; a) P. serratocostatus; b) P. asper; c) P. rossi; d) P. mawsoni.

number of serrations onthe middorsal carina. Moreover, the peduncle of uropod is longer than the inner rami in $L$. vanhoeffeni and of similar length in $L$. costatus. Leucon vanhoeffeni has been synonimized with L. kerguelensis by Lomakina (1968) but without discussion, the study of type material of both species has not furnished criteria for this synonimy.

Family LAMPROPIDAE Sars, 1878

Paralamprops asper Zimmer, 1907

Paralamprops aspera: Zimmer 1907, p. 373; Zimmer 1913, p. 457458, pl. 6 fig. 52-55.

Material examined: BENTART-95, sta. 30: 1 adult $q$ (without pleon), 1 preadult $\stackrel{+}{ }, 2$ preadult $\hat{\delta} \hat{\delta}$.

Remarks: Four species of genus Paralamprops have been recorded from the Antarctic waters: $P$. serratocostatus Sars, 1887, P. asper Zimmer, 1907, P. mawsoni (Hale, 1937) and P. rossi Jones, 1971. The carapace of the four species show similar structure, broad and flattened anteriorly but elevated at hind half, with a mid-dorsal carina on the anterior half and a lateral carina running round the sides of carapace. Between them there are three pairs of dorso-lateral ridges of different length and shape (Fig. 10). P. serratocostatus has the first and second dorso-lateral ridge as long as or longer than half carapace and the third very reduced, all ridges are serrated. P. mawsoni has the second and third ridge very reduced. $P$. rossi has the second ridge very short and located at the hind end of carapace (not figured in Jones, 1971) and the third extending backwards from the sides of pseudorostrum formed by two lobes with an interruption between them. Finally, $P$. asper is very similar to $P$. rossi but with the dorso-lateral ridges sligthly serrated and the third of them not interrupted.
Although the specimens of South Shetland Islands do not show spines on the integument, they have the third dorsolateral ridge continuous and the telson of same length as the uropod peduncle; moreover, the adult females have rudimentary exopods on pereopods 3 and 4 . This set of characters assign this material to Paralamprops asper.

\section{Paralamprops mawsoni (Hale, 1937)}

(Fig. 11)

Hemilamprops mawsoni: Hale 1937, p. 44-46, fig. 4, 5.

Material examined: BENTART-95 sta. 29, $240 \mathrm{~m}: 1$ preadult $q, 1$ preadult $\delta, 2$ jov.

Description: Preadult female total length 14.2 $\mathrm{mm}$ (from de tip of pseudorostrum to the end of last abdominal somite). Integument well calcified. Carapace (Fig. 11a, b) slightly less than one third of total length; mid-dorsal carina extending from the eyelobe to the half of carapace, one pair of abruptly elevated ridges running from the end of mid-dorsal carina to the posterior margin of carapace; a pair of short carina near hind margin and another located before it. Eyelobe formed by a pair of oval protuberances. Antennal notch distinct.

Pedigerous somites, each with two pair of dorsolateral protuberances. Pereopods 3 and 4 without traces of exopodites. Telson slightly shorter than uropod peduncle with three terminal spines.

First antenna peduncle of three articles (Fig. 11c), the proximal is clearly longer than the second which is sligthly longer than the third; main flagellum of six segments, the first is longer than the others; accessory flagellum of three segments and shorter than the main one. Third maxilliped (Fig. 11e) with basis longer than rest of limb and with plumose setae on its inner edge; ischium short; 
merus distally produced and rounded, carpus longer than propodus, both with abundant setation on inner edges; dactyl shorter than propodus. First pereopod (Fig. 11f) long and slender, basis shorter than the remaining segments together, with the distal part of inner edge serrated; ischium short; merus, carpus and propodus of increasing length, dactyl shorter than propodus and as long as merus. Second pereopod (Fig. 11g) with basis longer than the rest of limb; carpus longer than ischium and merus together and with spines on inner margin; propodus and dactyl combined length shorter than carpus. Uropod peduncle (Fig. 11d) shorter than the two last abdominal somites, inner margin with 12-13 spines.

Preadult male (carapace length $4.35 \mathrm{~mm}$ ) similar in shape to the female. With exopods on the peraeopod 1-4 and three pair of pleopods. Immature males as preadult but without traces of pleopods.

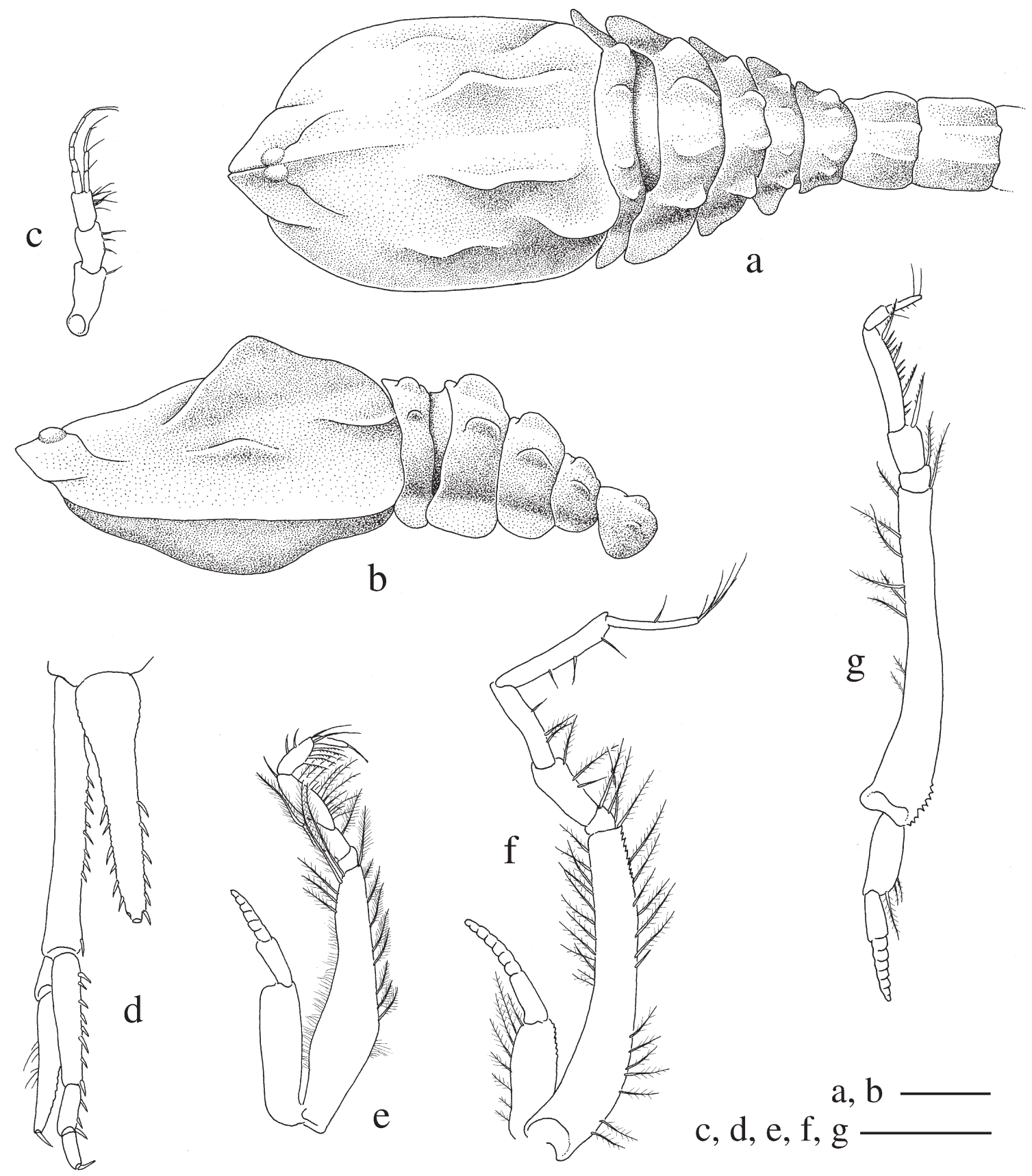

FIG. 11. - Paralamprops mawsoni (Hale, 1937) preadult female (a-c, e-g) and preadult male (d); a) carapace, thorax and first two abdominal somites in dorsal view; b) lateral view of carapace and thoracic somites; c) first antenna; d) uropod; e) third maxilliped; f) first pereopod; g) second pereopod. Scale bar $1 \mathrm{~mm}$. 
Remarks: This species was originally placed, with doubts, in the genus Hemilamprops. However, Jones (1969), Bacescu (1992) and Ledoyer (1993) moved this species to the genus Paralamprops due to the structure of uropod exopod and the general shape of the carapace. The lack of exopods on peraeopods 3 and 4 of female would place this species in the genus Platysympus, but there is doubt about the generic value of this character (Jones, 1971;
Ledoyer, 1993). The antennal notch, the three pairs of pleopods of the male and the shape of the carapace place this species in the genus Paralamprops.

\section{Distribution and ecological notes}

In total, 1236 specimens of cumaceans belonging to 25 species have been collected around South Shetland Islands during the BENTART cruise (Table

TABLE 1. - Abundance and bathymetric distribution of cumaceans found around South Shetland Islands during the BENTAR-95 cruise.

\begin{tabular}{|c|c|c|c|c|c|c|c|c|c|c|c|c|c|c|c|c|c|c|c|c|c|}
\hline STATION & $\mathrm{T} 6$ & $\mathrm{~T} 27$ & $\begin{array}{l}\text { T3 } \\
89\end{array}$ & T23 & $\begin{array}{l}\mathrm{T} 17 \\
107\end{array}$ & T28 & $\begin{array}{l}\text { T9 } \\
163\end{array}$ & $\begin{array}{l}\mathrm{T} 11 \\
167\end{array}$ & $\begin{array}{l}4 \mathrm{~T} 1 \\
176\end{array}$ & $\begin{array}{l}4 \mathrm{~T} 2 \\
188\end{array}$ & $\mathrm{~T} 10$ & T19 & T29 & $\begin{array}{l}\text { T5 } \\
262\end{array}$ & $\mathrm{~T} 22$ & T15 & $25 \mathrm{~T} 1$ & $25 \mathrm{~T} 2$ & T21 & $\mathrm{T} 16$ & $\begin{array}{l}\mathrm{T} 30 \\
649\end{array}$ \\
\hline & & & & & & 124 & & & $1 / 6$ & & & & & & & & & & & & \\
\hline Diastylis helleri. & 1 & & & & & & & & & & & & & & & & & & & & \\
\hline Diastylis mawsoni & & & & & & 1 & & & & & & & & & & & & & & & \\
\hline Eudorella gracilior & & & 9 & & & 15 & 3 & & 30 & 1 & 2 & & & & & & & & & & \\
\hline Campylaspis breviramis & & & 1 & 1 & & & 2 & & 3 & & 2 & 2 & 1 & & & & & & & & \\
\hline Leucon (Crym.) costatus & & & 21 & & & 26 & 92 & & 57 & 25 & 58 & & & 6 & & & & & & 1 & \\
\hline Cumella australis & 9 & & & & & 1 & & & & 2 & & 3 & 4 & & & & & & & & 5 \\
\hline Vaunthompsonia spp (manca) & 47 & & 76 & & 4 & 37 & 23 & & 6 & 2 & 2 & & & & & 2 & & & & & \\
\hline Vaunthompsonia meridional & & & 62 & & & 188 & 5 & 1 & 10 & & 5 & & & & & & & & & 1 & \\
\hline Vaunthompsonia laevifrons & 43 & & 9 & & 1 & 2 & & & & 1 & & 5 & 3 & 1 & & 9 & 1 & 2 & & 63 & 9 \\
\hline Leptostylis crassicauda & 1 & & & & & 3 & & & & & 1 & & & & & 2 & & & 1 & 6 & 7 \\
\hline Diastylopsis goekei & & 5 & & & & 41 & & & 2 & & & & & & & 1 & 5 & & 1 & 6 & \\
\hline Diastylis anderssoni & & & & & & 1 & & & & & & & & & & & & & & 3 & \\
\hline Diastylis inornata & & & & & & 10 & & & & & & & 4 & & & & & & & & 2 \\
\hline Hemilamprops ultimaespei & & & & & & 16 & 1 & & & & & & 13 & & 6 & & & & 2 & & 4 \\
\hline Paralamprops mawsoni & & & & & & & & & & & & & 4 & & & & & & & & \\
\hline Cyclaspis gigas & & & & & & & & & & & 1 & & 1 & & & & & & & & \\
\hline Campylaspis frigida & & & & & & & & & & & 1 & 2 & & & & & & & & & \\
\hline aspis heterotuberculata & & & & & & & & & & & & & & & 2 & & & & & & \\
\hline Leucon (Leucon) a & & & & & & & & & & & & 3 & & & & & 1 & & 3 & 2 & 3 \\
\hline Campylast & & & & & & & & & & & & & 8 & & & & & & & & 5 \\
\hline Proca & & & & & & & & & & & & & & & & & 2 & & 2 & & \\
\hline Diastylis corniculata & & & & & & & & & & & & & 1 & & & 2 & & & & 2 & 1 \\
\hline (Crym.) intermedius & & & & & & & & & & & & & & & & & & 1 & & & 1 \\
\hline Paralamprops asper & & & & & & & & & & & & & & & & & & & & & 4 \\
\hline Cume & & & & & & & & & & & & & & & & & & & & & 3 \\
\hline halei & & & & & & & & & & & & & & & & & & & & & 10 \\
\hline Campylaspis sp.* & 1 & & & & & & & & 4 & & 1 & & & & & & 1 & & 2 & & \\
\hline Diastylopsis sp* & & & & & & & 1 & & & & & & & & & & & & 1 & & \\
\hline Indeterminated species* & & & & & & & & & 1 & & & & 1 & & & & & & & 6 & 4 \\
\hline Total i & 102 & 5 & 178 & 1 & 5 & 341 & 127 & 1 & 113 & 31 & 73 & 15 & 40 & 7 & 8 & 16 & 10 & 3 & 12 & 90 & 58 \\
\hline Total species & 4 & 1 & 5 & 1 & 1 & 11 & 5 & 1 & 5 & 4 & 7 & 5 & 9 & 2 & 2 & 4 & 4 & 2 & 5 & 8 & 12 \\
\hline Diversity (Shanon-Weaver Inder & 0.59 & 0 & 1.12 & 0 & 0.7 & 1.77 & 1.15 & 0 & 1.66 & 0.99 & 1.21 & 2.23 & 2.80 & 0.59 & 0.81 & 1.37 & 1.66 & 0.91 & 2.19 & 1.43 & 3.3 \\
\hline
\end{tabular}

* Damaged specimens

TABLE 2. - Total abundance $\left(\mathrm{N}_{\mathrm{t}}\right)$ of the main cumacean species in the 10-50 cm $\left(\mathrm{N}_{1}\right), 55-90 \mathrm{~cm}\left(\mathrm{~N}_{2}\right)$ and $100-140 \mathrm{~cm}\left(\mathrm{~N}_{3}\right)$ near-bottom layers sampled with the three nets of the sled, and the swimming activity indices $\left(\mathrm{K}_{1}=\mathrm{N}_{2} / \mathrm{N}_{\mathrm{t}}\right.$ and $\left.\mathrm{K}_{2}=\mathrm{N}_{3} / \mathrm{N}_{\mathrm{t}}\right)$.

\begin{tabular}{|c|c|c|c|c|c|c|}
\hline & $\mathrm{Nt}$ & N1 & $\mathrm{N} 2$ & N3 & K1 & $\mathrm{K} 2$ \\
\hline Vaunthompsonia laevifrons & 149 & 152 & 6 & 1 & 0.03 & 0.01 \\
\hline Vaunthompsonia meridionalis & 272 & 261 & 11 & 0 & 0.04 & 0 \\
\hline Vaunthompsonia spp. (manca stage) & 199 & 168 & 27 & 4 & 0.14 & 0.02 \\
\hline Leucon costatus & 286 & 192 & 58 & 36 & 0.20 & 0.13 \\
\hline Eudorella gracilior & 60 & 51 & 8 & 1 & 0.13 & 0.02 \\
\hline Cumella australis & 24 & 19 & 2 & 3 & 0.08 & 0.13 \\
\hline Diastylis inornata & 16 & 15 & 1 & 0 & 0.06 & 0 \\
\hline Diastylopsis goekei & 61 & 54 & 4 & 3 & 0.07 & 0.05 \\
\hline Leptostylis crassicauda & 21 & 12 & 9 & 0 & 0.43 & 0 \\
\hline Hemilamprops ultimaespei & 42 & 36 & 3 & 3 & 0.08 & 0.07 \\
\hline Total & 1236 & 1047 & 145 & 54 & 0.12 & 0.04 \\
\hline
\end{tabular}




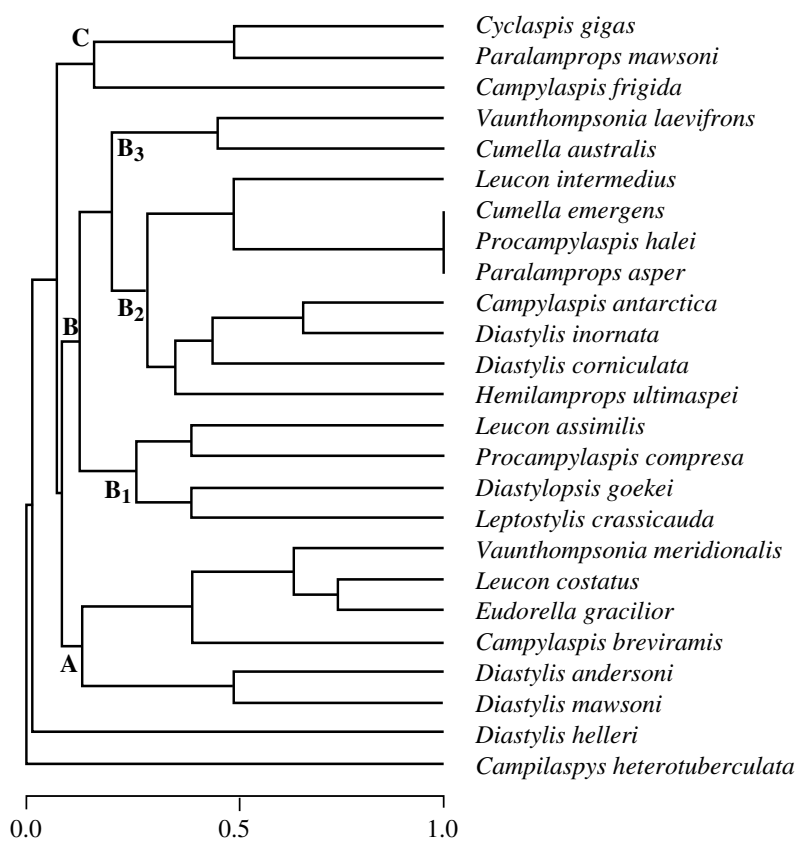

FIG. 12. - Dendrogram of similarities (using Jaccard's index and UPGMA aggregation algorithm) between the 25 cumacean species collected during BENTART-95 cruise.

1). Cumaceans were absent from three sampling stations $(2,11$ and 18) located in the Deception Island caldera and the other two sampling stations of this area (11 and 17) showed lower abundances. Higher abundance (341 ind.) was observed at station 28 in north of Livingston Island.

The highest number of species was observed at three stations in the north of Livingston Island (28, 29 and 30) and the deepest of them (sta. 30) showed the maximum number (13 species). The diversity index (Table 1) follows a similar trend of species number and increases significantly with depth.
All species of cumaceans showed a clear vertical distribution gradient with a decrease of abundance from the $10-50 \mathrm{~cm}$ to the $100-140 \mathrm{~cm}$ water layers above the bottom. Within the most abundant species, Leucon costatus had the highest swimming coefficients $\left(\mathrm{K}_{1}=0.2 ; \mathrm{K}_{2}=0.13\right)$ (Table 2$)$. Leptostylis crassicauda was only recorded in the two water layers near the bottom (10-50 cm and 55-95 $\mathrm{cm})$, but with a similar proportion $\left(\mathrm{K}_{1}=0.43\right)$. Mancas of two species of Vaunthompsonia showed higher values of these coefficients $\left(\mathrm{K}_{1}=0.14 ; \mathrm{K}_{2}=0.02\right)$ than the remaining specimens (preadults females, preadult males and adult females).

Cluster analysis (Fig. 12) discriminated species in three groups. Group A was composed of species inhabiting above $300 \mathrm{~m}$ depth, as Eudorella gracilior, Leucon costatus and Vaunthompsonia meridionalis. Group C was only formed by Campylaspis frigida, Paralamprops mawsoni and Cyclaspis gigas which were collected between 221 and $242 \mathrm{~m}$ depth. Finally, group B was composed by euribathic species (subgroup $\mathrm{B}_{1}$ and $\mathrm{B}_{3}$ ) as well as by species collected below $300 \mathrm{~m}$ depth (subgroup $\mathrm{B}_{2}$ ). In this last subgroup, Paralamprops asper, Procampylaspis halei and Cumella emergens were only collected at the deeper station (649 $\mathrm{m}$ depth).

The ordination of species on the axis representing the first two factors in the PCA (Fig. 13) shows that the first factor, which explains $29.6 \%$ of the total variance, clearly segregated the species Campylaspis breviramis, Leucon costatus, Eudorella gracilior and Vaunthompsonia meridionalis from the rest of the species considered. Correlation (Spearman rank) between the species scores and the

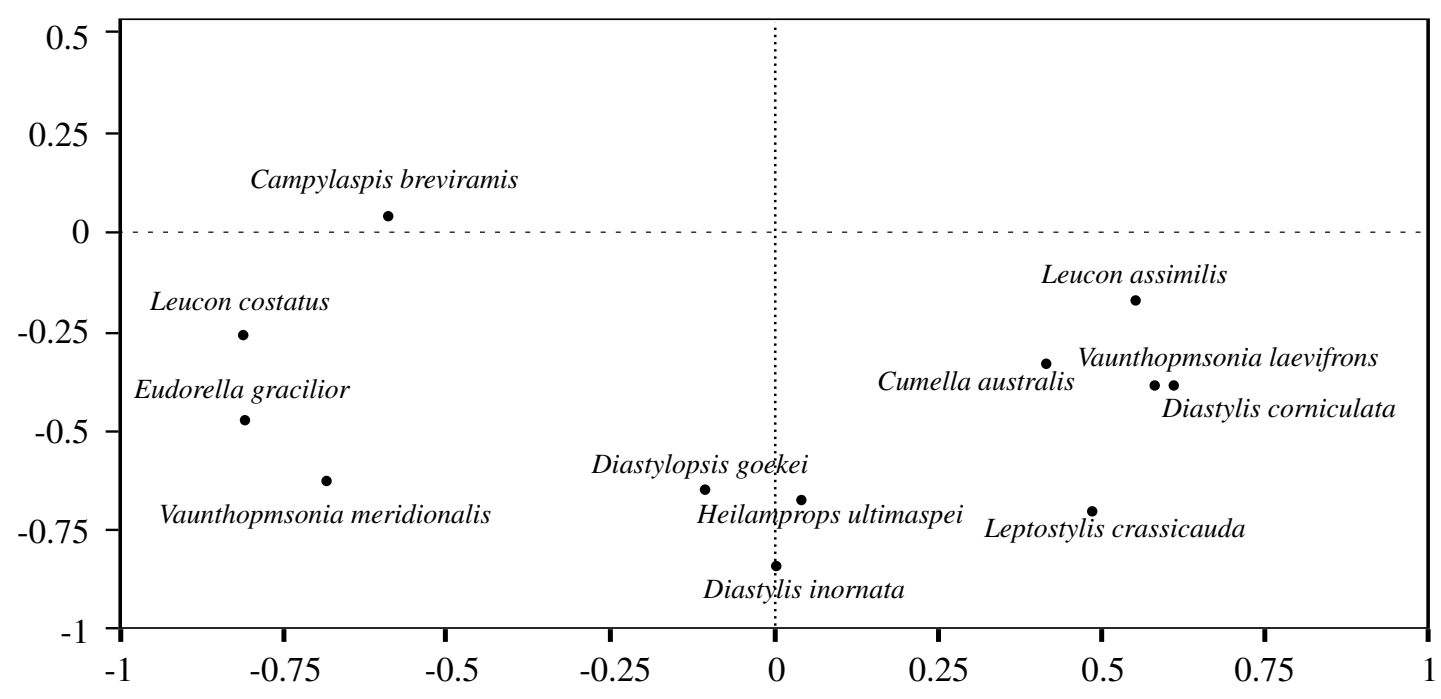

FIG. 13. - Principal Component Analysis (PCA) performed with the 12 most frequent cumacean species. 
environmental parameters (depth, \% of organic matter content, sediment median grain size, and redox potential) determined that is depth the main parameter affecting the species distribution.

\section{DISCUSSION}

The 25 species found around the South Shetland Islands represent $36 \%$ of total species recorded from the Antarctic and Subantarctic waters. This species number is similar to the one reported from Weddell Sea (Ledoyer, 1993) but significantly greater than the number observed in Ross Sea by Jones (1971). The lower values of abundance and species number observed in Deception Island caldera has been attributed to the recent volcanic activity that could have destroyed benthic communities (Gallardo, 1992). The present acidic conditions in the surperficial sediments (San Vicente et al., 1997) may also have contributed.

Diversity increases with depth and it is higher at the deepest station $(649 \mathrm{~m})$ on the continental slope in the North of Livingston Island. High values of diversity and species number were also reported from cumacean assemblages of bathyal bottoms in Bay of Biscay (Elizalde et al., 1993) and western Mediterranean (Cartes and Sorbe; 1997). The continental slope is a region with the most intensive water column activity caused by boundary currents and it is here where one would expect speciation to be very active (Wilson and Hessler, 1987).

Recent studies on suprabenthic communities have provided data on the swimming activity of cumaceans (Elizalde et al., 1993; Dauvin and Zouhiri, 1996; Cartes and Sorbe, 1997). These crustaceans show a marked vertical gradient with a maximum abundance in the nearest bottom water layer. In the continental slope of the Catalan Sea (western Mediterranean), Cartes and Sorbe (1997) reported intraspecific differences of swimming coefficients. In some species, adult males showed higher swimming coefficients, specially for Leucon longirostris and Diastyloides serratus. A male of this last species was captured by a sediment trap located $30 \mathrm{~m}$ above the bottom in the same area (Gili, pers. com.). While for shallow water species, vertical movements mainly by adult males, have a circadian rhythm that is controlled by changes of irradiance (Macquard-Moulin, 1991); no data are known on the factors and rhythms affecting the movements of deep water species. During the
BENTART-95 cruise no adult male was collected, however, intraspecific differences of swimming activity were observed for the genus Vaunthompsonia. Mancas of this genus showed higher activity than the preadults and adults. This behaviour could favour the dispersion of these crustaceans which do not have a planktonic larval stage.

In the South Shetland Islands the main environmental parameter affecting distribution of cumaceans was depth. This seems to be a common factor observed in the western Mediterranean (Corbera and Cardell, 1995) and on the Brazilian coast (Dos Santos and Pires-Vanin, 1999).

Based on bathymetric distribution, three groups of species can be distinguished. A group of species distributed between 45 and $300 \mathrm{~m}$ depth, a second group collected between 300 and $650 \mathrm{~m}$ depth and finally species that co-occur in both deep ranges. In the Weddell Sea, Ledoyer (1993) reported a group of species inhabiting between 200 and 500-600 m depth, a second group of deep-sea species distributed below $500 \mathrm{~m}$ depth and a group of species with wide distribution (between 200 and $2000 \mathrm{~m}$ ). It is difficult to establish comparison between two studies because while bottoms shallower than $200 \mathrm{~m}$ in the Weddell Sea are not accessible due to the iceshelf, bottoms below $650 \mathrm{~m}$ were not sampled during the present study. However, the increase of species at station 30 of the present study $(649 \mathrm{~m}$ depth) could corroborate the change of cumacean assemblages around 500-600 m suggested by Ledoyer in the Weddell Sea.

\section{Distribution and biogeography of Antarctic Cumaceans}

To my knowledge, 68 species have been described from Antarctic and Subantarctic waters (excluding the Magellan region) (Table 3). Eightyseven percent of these species were found between 50 to $700 \mathrm{~m}$ depth. Between 50 and $300 \mathrm{~m}$ depth 47 species were found and between 300 and $700 \mathrm{~m}$ depth 38 species. In shallow bottoms (upper $50 \mathrm{~m}$ depth) only 18 species have been recorded, three of these species, Leucon kerguelensis, L. vanhoeffeni and $L$. inexcavatus are exclusive for shallow bottoms and are confined to Kerguelen Island. The low number of species in shallower bottoms may be due, as in other faunistical groups, to the scarcity of this type of habitat in Antarctida and to the impact of the ancor ice and iceberg scour (Arntz et al., 1994) 
TABLE 3. - Regional and bathymetrical distribution of Antarctic cumaceans. EA, Eastern Antarctica; WS, Weddell Sea; AP, Antarctic Peninsula and Bellingshausen Sea (including South Shetland Islands); RS, Ross Sea; KI, Kerguelen Island; SG, South Georgia.

\begin{tabular}{|c|c|c|c|c|c|c|c|}
\hline Species & Depth range (m) & AP & WS & EA & $\mathrm{RS}$ & KI & SG \\
\hline Campylaspis maculata & $6-250$ & - & & & & & \\
\hline Campylaspis heterotuberculata & 240 & - & & & & & \\
\hline Leucon (Crymoleucon) costatus & $89-427$ & - & & & & & \\
\hline Cumella emergens & 650 & - & & & & & \\
\hline Procampylaspis halei & 650 & - & & & & & \\
\hline Leucon (Macrauloleucon) parasiphonatus & $363-424$ & - & • & & & & \\
\hline Campylaspis breviramis & $457-462$ & - & • & & & & \\
\hline Hemilamprops ultimaespei & $12-1223$ & - & - & & & & \\
\hline Diastylopsis goekei & $2-430$ & • & • & & - & & \\
\hline Procampylaspis compressa & $350-1223$ & - & - & - & & & \\
\hline Gaussicuma vanhoeffeni & $1996-3423$ & - & - & - & & & \\
\hline Leucon (Leucon) assimilis & $150-650$ & • & $\bullet$ & - & & & \\
\hline Diastylis mawsoni & $124-582$ & • & • & - & & & \\
\hline Leptostylis crassicauda & $50-1223$ & - & - & • & & & \\
\hline Diastylis anderssoni & $124-810$ & - & - & - & & & - \\
\hline Cumella australis & $50-650$ & • & - & - & - & & \\
\hline Cyclaspis gigas & $160-700$ & - & • & - & - & & \\
\hline Campylaspis antarctica & $193-522$ & - & - & - & - & & \\
\hline Eudorella gracilior & $15-752$ & $\bullet$ & - & - & • & & - \\
\hline Diastylis helleri & $0-70$ & • & - & • & - & & - \\
\hline Eudorella splendida & $0-310$ & - & & - & - & - & - \\
\hline Paralamprops asper & $385-650$ & - & & - & • & & \\
\hline Cumella pectinifera & $275-283$ & - & & - & & & \\
\hline Leucon (Crymoleucon) intermedius & $280-791$ & - & & - & & & \\
\hline Paralamprops mawsoni & $240-300$ & • & & - & & & \\
\hline Platysympus brachyurus & 385 & - & & - & & & \\
\hline Diastylis corniculata & $218-650$ & • & & - & & & • \\
\hline Vaunthompsonia inermis & $24-650$ & • & & & & & • \\
\hline Vaunthompsonia meridionalis & $15-310$ & - & & & & • & • \\
\hline Campylaspis frigida & 24-2011 & - & & & & • & \\
\hline Diastylis inornata & $124-650$ & - & & & & - & \\
\hline Campylaspis johnstoni & $193-2018$ & & - & • & & - & \\
\hline Vaunthompsonia laevifrons & $123-577$ & & - & - & & & \\
\hline Campylaspis quadriplicata & $165-2707$ & & - & - & & & \\
\hline Leucon (Crymoleucon) antarcticus & $69-752$ & & - & - & - & & \\
\hline Paralamprops rossi & 406-705 & & - & - & - & & \\
\hline Makrokylindrus inscriptus & 799-2012 & & - & & - & & \\
\hline Leucon (Macrauloleucon) weddelli & $399-537$ & & - & & & & \\
\hline Leucon (Alytoleucon) polarsterni & $1153-1223$ & & - & & & & \\
\hline Atlantocuma elongatum & $506-839$ & & • & & & & \\
\hline Campylaspis quadridentata & $406-506$ & & - & & & & \\
\hline Campylaspis excavata & $185-515$ & & - & & & & \\
\hline Diastylis enigmatica & $270-280$ & & - & & & & \\
\hline Diastylis galeronae & $1165-2012$ & & - & & & & \\
\hline Diastylis pseudoinornata & 90 & & - & & & & \\
\hline Lamprops comatus & 3423 & & - & & & & \\
\hline Cyclaspis cristulata & $276-279$ & & & - & & & \\
\hline Leucon (Crymoleucon) breidens & $275-283$ & & & • & & & \\
\hline Schizocuma molossa & 385 & & & - & & & \\
\hline Diastylopsis diaphanes & 385 & & & - & & & \\
\hline Hemilamprops pellucidus & $226-3725$ & & & - & & & \\
\hline Campylaspis nodulosa & $1-5000$ & & & - & & - & \\
\hline Diastylopsis annulata $(=D$. dentifrons $)$ & 4-355 & & & - & & - & • \\
\hline Procampylaspis meridiana & 110 & & & & - & & \\
\hline Cyclaspis kerguelenensis & 195 & & & & & • & \\
\hline Leucon (Crymoleucon) kergelensis & $5-10,5$ & & & & & - & \\
\hline Leucon (Crymoleucon) vanhoeffeni & $1-3$ & & & & & - & \\
\hline Leucon (Crymoleucon) inexcavatus & 31 & & & & & - & \\
\hline Diastylis horrida & $20-540$ & & & & & - & \\
\hline Diastylis zimmeri & $18-90$ & & & & & - & \\
\hline Hemilamprops serrulatus & 195 & & & & & • & \\
\hline Paralamprops serratocostatus & 230 & & & & & • & \\
\hline Kerguelenica platycephala & 195 & & & & & - & \\
\hline Cimmerius subantarcticus & 196 & & & & & • & \\
\hline Leucon (Crymoleucon) sagitta & $12-310$ & & & & & - & - \\
\hline Eudorella fallax & $64-610$ & & & & & & - \\
\hline Cyclaspis quadrituberculata & 75 & & & & & & - \\
\hline Leptostylis antipus & $12-310$ & & & & & & - \\
\hline
\end{tabular}


Only 14 species live below $700 \mathrm{~m}$ depth and, three of them, named Gaussicuma vanhoeffeni, Hemilamprops pellucidus and Lamprops comatus were found below $2500 \mathrm{~m}$ depth. Lamprops comatus is the only species which can only be found in abyssal bottoms (below $2500 \mathrm{~m}$ ). Within the 14 deep-water species, eight of them show a wide range of bathymetric distribution.

The species number is maximum between 50 and $700 \mathrm{~m}$ depth and decreases drastically in lower parts. This pattern of distribution contrasts with the one observed in other oceans. In the Atlantic, Jones and Sanders (1972) found the highest species number between 1000 and $2000 \mathrm{~m}$ depth and the number of species is not significantly lower below $4000 \mathrm{~m}$ depth. In the Mediterranean, the maximum of species number was observed between 2000 and $3000 \mathrm{~m}$ (Reyss, 1973). Low species number in Antarctic deepest bottoms may be due to low-sampling effort there.

The total species found in Antarctic waters (High Antarctic and Subantarctic regions) represents less than $6 \%$ of the cumacean world fauna (currently around 1250 species). Antarctic cumaceans show a high degree of endemism ( $91 \%$ of species). Only six species recorded in Antarctica are common with other geographical regions: Hemilamprops pellucidus from the southern Atlantic Ocean and Hemilamprops ultimaspei, Campylaspis johnstoni, $C$. nodulosa, $C$. frigida and C. quadriplicata from the South American coasts. However, at a generic level the degree of endemism is very low (5.3\%), only the genera Kerguelenica is endemic and was found only in the Kerguelen Island. The high level of endemism is a striking feature of the Southern Ocean (Clarke and Crame, 1989; Arntz et al., 1997) and is observed in many benthic groups as isopods (Brandt, 1992), amphipods (Jazdzewski, et al., 1991), pycnogonids (Fry, 1964) and bryozoans (Hayward, 1995) and may be due to the isolation of Antarctica from the other continents after the opening of the Drake Passage and the posterior development of circumantarctic current (Clarke and Crame, 1989; Brandt, 1992; Arntz et al., 1994).

High Antarctic regions have a higher number of species than Subantarctic regions, and in the Antarctic Peninsula and in the Bellingshausen Sea is where this number is higher ( 32 species, Table 4 ). The four High Antarctic regions considered, East Antarctica, Weddell Sea, Antarctic Peninsula (including Bellingshausen Sea) and Ross Sea have a high number of species in common. On the other hand, the
TABLE. 4. - Endemism of cumaceans of the Subantarctic and High Antarctic regions. N: number of species recorded in the region. End. Sp.: number of endemic species.

\begin{tabular}{lrrr}
\hline Region & $\mathrm{N}$ & End. Sp. & $\%$ \\
\hline East Antarctica & 30 & 4 & 13.3 \\
Wedell Sea & 29 & 8 & 27.6 \\
Antarctic Peninsula and & & & \\
Bellingshausen Sea & 32 & 6 & 18.7 \\
Ross Sea & 12 & 1 & 8.3 \\
Kerguelen Islands & 18 & 10 & 55.6 \\
South Georgia & 12 & 3 & 25.0 \\
& & & \\
\hline
\end{tabular}

Kerguelen Island and South Georgia, have few species in common and compared with the High Antarctic regions. The Ross Sea and the Weddell Sea also have one species in common with the Kerguelen Island.

By regions, the Weddell Sea shows the highest percentage of endemism within the High Antarctic regions (28\%) and the Ross Sea shows the lowest (9\%) (Table 4), but Subantarctic regions have a more elevated endemism than High Antarctic regions (25\% in South Georgia and 56\% in the Kerguelen Island).

Phylogeny of cumaceans is practically unknown, thus, it is difficult to establish the origin of Antarctic cumacean fauna. Based on the biogeographic distribution and assuming the actual systematic classification is based on phylogeny, it seems to be clear that cumaceans do not have a common and recent origin as proposed by Sieg (1988). Different processes may contribute to the establishment of the present fauna of cumaceans as has been postulated by Clarke and Crame (1989) for the whole marine fauna and quite similar for isopods (Brandt, 1992).

Four Antarctic species of genus Campylaspis also live in the Magellan region. Both faunas may have a common origin that diverged after the separation of the two continents and the posterior establishment of circumantarctic current (4.3-1.6 Ma) as Watling and Thurston (1989) have proposed for the amphipod family Iphimediidae.

However, another hypothesis would explain the present distribution of genus Campylaspis. The four species that also live in South American show a very wide bathymetrical range of distribution and would have colonized Antarctica through the Scotia Arc.

Eight species of the subgenus Crymoleucon inhabit only Antarctic shallow waters while a similar number is distributed in deep water of the Mediterranean Sea, the Indic Ocean, the Pacific Ocean and the Atlantic Ocean. This pattern of distribution suggests 
that subgenus Crymoleucon would have originated in Antarctic shallow waters and later, colonised deep water favoured by the similar physical conditions of the water masses. This phenomenon of submergence has been suggested for the isopod family Serolidae and subfamily Arcturinae (Brandt, 1992).

An opposite phenomenon is known for the deep fauna. Deep water species evolved and diversified in the deep sea favoured by the long time environmental stability (Lipps and Hickman, 1982) and some species could colonise continental shelves mainly in high latitudes (Hessler and Thistle, 1975; Knox and Lowry, 1977; Lipps and Hickman, 1982; Hessler and Wilson, 1983). This process of emergence could be followed by Cumella emergens which would evolve from the Atlantic deep water group of this genus (see Jones, 1984) and by the species of family Lampropidae and Diastylidae.

The only Antarctic species of the family Pseudocumatidae, Kerguelenica platycephala, described from Kerguelen Islands is of special interest. Species of the family Pseudocumatidae are currently distributed mainly in the Caspian Sea, the Azov Sea, the Black Sea, the Mediterranean Sea and the northeastern Atlantic (Bacescu, 1992) and it suggests a Tethyan origin for this family. Kerguelenica platycephala may be a paleoendemism originated in the early Cretaceous when the Tethys Sea surrounded northern Gondwana. Relict species would have survived the ice ages in faunistic refuges as was pointed out by Brandt (1992) and supported by the current presence of a benthic community under the shelf-ice (Bruchhausen et al., 1979; Lipps et al., 1979).

Further studies on the phylogeny as well as on the deep Antarctic fauna of cumaceans will supply important data which could contribute to explain the evolution of cumaceans in this area.

\section{ACKNOWLEDGEMENTS}

The BENTART cruises were carried out under the auspices of two Spanish Council of Scientific and Technical Research (CICYT) Antarctic Programmes (ANT 93-0996 and ANT 94-1161-E). I am very grateful to Dr. A. Ramos, scientist in charge of the BENTART cruises, and Dr. C. San Vicente for offers me the opportunity to study this cumacean collection, to Dr. J.M. Gili for facilities at the Institut de Ciències del Mar (CSIC), to Dr. C.O. Coleman for the loan of type material from the Museum für Naturkunde der Humboldt-Universität zu Berlin, to Dr. A. Garcia-Rubies for help in statistical treatment of data and to Mr. R. Coppens who revised the English version of the manuscript. I am very indebted to Dr. F. Pagès for comments and criticism on the first draft of manuscript. SEM microphotograph was performed in the Serveis Cientifico Tècnics of the University of Barcelona.

\section{REFERENCES}

Arntz W.E., T. Brey and V.A. Gallardo. - 1994. Antarctic zoobenthos. Oceanogr Mar Biol Ann Rev 32: 241-304.

Arntz, W.E., J. Gutt and K. Klages. - 1997. Antarctic marine biodiversity: an overview. In: B. Battaglia, J. Valencia and D.W.H. Walton (eds.), Antarctic communities, species, structure and survival, pp. 3-14. Cambridge University Press.

Bacescu, M. - 1992. Cumacea II (Fam. Nannastacidae, Diastylidae, Pseudocumatidae, Gynodiastylidae et Ceratocumatidae). In: H.E. Gruner and L.B. Holthuis (eds.), Crustaceorum Catalogus Pars 8, pp. 175-468. SPB Academic Publishing, The Hague.

Blazewicz, M. and K. Jazdzewski. - 1995. Cumacea (Crustacea, Malacostraca) of Admiralty Bay, King George Island: a preliminary note. Pol. Polar Res., 16: 71-86.

Brandt, A. - 1992. Origin of Antarctic Isopoda (Crustacea, Malacostraca). Mar. Biol., 113: 415-423.

Brandt, A. - 1993. Composition, abundance and diversity of peracarid crustaceans on a transect of the Kolbeinsey Ridge, north of Iceland. Polar Biol., 13: 565-576.

Brandt, A. - 1995. Peracarid fauna (Crustacea, Malacostraca) of the Northeast Water Polynya off Greenland: documenting close benthic-pelagic coupling in the Westwind Trough. Mar. Ecol. Prog. Ser., 121: 39-51.

Bruchhausen, P.M., J.A. Raymond, S.S. Jacobs, A.L. De Vies, E.M. Thorndike and H.H. DeWitt. - 1979. Fish, crustaceans, and the sea floor under the Ross Ice Shelf. Science, 203: 449-451.

Brunel, P. - 1972. The Gaspe cod ecosystem in the Gulf of St. Lawrence. III. The daily and seasonal vertical migrations of cod (Gadus morhua) in 1960-62. Nat. Can., 99: 287-357.

Brunel, P., M. Bresner, D. Messier, L. Poirer, D. Granger, and M. Weinstein. - 1978. Le traîneau Macer-GOROQ: appareil amélioré pour l'échantillonage quantitatif étagé de la petite faune nagueuse au voisinage du fond. Int. Rev. Ges. Hydrobiol., 63: 815-829.

Calman, W.T. - 1905. The marine fauna of the west coast of Ireland. Part IV. Cumacea. Fish. Ireland Sci. Invest., 1904, I: 3-52.

Cartes, J.E. - 1993. Diets of two deep-sea decapods: Nematocarcinus exilis (Caridea: Namatocarcinidae) and Munida tenuimana (Anomura: Galatheidae) on the Western Mediterranean slope. Ophelia, 37: 213-229.

Cartes, J.E. and J.-C Sorbe. - 1997. Bathyal cumaceans of the Catalan Sea (North-western Mediterranean): faunistic composition, diversity and near-bottom distribution along the slope (between 389 and $1859 \mathrm{~m})$. J. Nat. Hist., 31: 1041-1054.

Cartes, J.E., J.-C Sorbe and F. Sarda. - 1994. Spatial distribution of deep-sea decapods and euphausiids near the bottom in the northwestern Mediterranean. J. Exp. Mar. Biol. Ecol., 179: 131-144.

Clarke, A. and J.A. Crame. - 1989. The origin of the Southern Ocean marine fauna. In: J.A. Crame (ed.), Origins and evolution of the Antarctic biota, pp. 253-268. Geological Society Special Publication, 47. London.

Corbera, J. and M.J. Cardell. - 1995. Cumaceans as indicators of eutrophication on soft bottoms. Sci. Mar., 59 (Sup. 1): 63-69.

Dauvin, J.-C. and J.-C. Lorgeré. - 1989. Modification du traîneau Macer-GIROQ pour l'amélioration de l'échantillonnage quantitatif étagé de la faune suprabentique. J. Rech. oceanogr., 14: 65-67.

Dauvin, J.-C. and S. Zouhiri. - 1996. Suprabenthic crustacean fauna of a dense Ampelisca community from the English Channel. $J$. mar. biol. Ass. U.K., 76: 909-929.

Dos Santos , M.F.L. and A.M.S. Pires-Vanin. - 1999. The Cumacea community of the south-eastern Brazilian Continental Shelf: structure and dynamics. Sci. Mar., 63: 15-25. 
Elizalde, M., J.-C. Sorbe and J.C. Dauvin. - 1993. Las comunidades suprabentónicas batiales del golfo de Vizcaya (margen del cañon de Cap Ferret): composición faunística y estructura. Publ. Esp. Inst. Esp. Oceanogr., 11: 247-258.

Fage, L. - 1951. Cumacés. Faune de France 54:1-136. Paul Lechevalier, Paris.

Fry, W.G. - 1964. The pycnogonid fauna of the Antarctic continental shelf. In: R. Carrick, M. Holdgate and J. Prévost (ed.), Biologie Antarctique, pp. 263-270. Herman, Paris.

Gallardo, V.A. - 1992. Estudios bentónicos en bahías someras Antárticas del Archipielago de las Islas Shetland del Sur. In: V.A. Gallardo, O. Ferrari and H.I. Moyano (eds.), Ocreanografía en Antártida, pp. 383-393. Centro Eula, Univ. Concepción. Concepción, Chile.

Gamô, S. - 1987. Cumacean Crustaceans obtained by the 26th Japanese Antarctic Research Expedition (1984-1985), with descriptions of four new species. Proc. NIPR Symp. Polar Biol., 1: $145-160$.

Hale, H.M. - 1937. Cumacea and Nebaliacea. Rep. B.A.N.Z. Antar. Res. Exp. 4(2): 37-56.

Hayward, P.J. - 1995. Antarctic Cheilostomous Bryozoa. 355 pp.

Hessler, R.R. and D. Thistle. - 1975. On the place of the origin of deep-sea isopods. Mar. Biol., 32: 155-165.

Hessler, R.R. and G.D.F. Wilson. - 1983. The origin and biogeography of malacostracan crustaceans in the deep sea. In: R.W. Sims, J.H. Price and P.E.S. Whalley (eds.), Evolution, time and space: The emergence of the biosphere, pp. 227-254. Academic Press, London and New York.

Jazdzewski, K., W. Teodorczyk, J. Sicinski and B. Kontek. - 1991. Amphipod crustaceans as an important component of zoobenthos of the shallow Antarctic sublittoral. Hydrobiologica, 223: 105-117.

Jones, N.S. - 1969. The systematics and distribution of cumacea from depths exceeding 200 meters. Galathea Report, 10: 99-180.

Jones, N.S. - 1971. The fauna of the Ross Sea. Part 8. Cumacea. Bull. N.Z. Dep. scient. ind. Res., 206: 33-41.

Jones, N.S, - 1984. The family Nannastacidae (Crustacea: Cumacea) from the deep Atlantic. Bull. Brit. Mus. (Nat. Hist.), 46(3): 207-289.

Jones, N.S. and H.L. Sanders. - 1972. Distribution of Cumacea in the deep Atlantic. Deep Sea Res., 19: 737-745.

Knox, G.A. and J.K. Lowry. - 1977. A comparison between the benthos of the Southern Ocean and the North Polar Ocean with special reference to the Amphipoda and the Polychaeta. In: M.J. Dunbar (ed.), Polar Oceans, pp. 423-462. Arctic Institute of North America, Calgary.

Kurian, C.V. and A. Radhadevi. - 1986. Distribution of Cumacea along Indian coasts. In: M.E. Thompson, R. Sarajoni and R. Naghabushanam (eds.), Biology of benthic organisms: Techniques and methods as applied to the Indian Ocean, pp. 289-296.

Ledoyer, M. - 1974. Sur une petite collection de cumacés recueillis aux îles Kerguelen. Tethys, 5(4): 709-714.

Ledoyer, M. - 1977. Cumacés (Crustacea) des îles Kerguelen recueillis par le N. O. La Japonaise en 1972 et 1974 et par le M.S. Marion-Dufresne en 1974. CNFRA, 42: 193-213.

Ledoyer, M. - 1993. Cumacea (Crustacea) de la campagne EPOS 3 du R.V. Polarstern en mer de Weddell, Antarctique. J. Nat. Hist., 27: 1041-1096.

Lipps, J.H. and C.S. Hickman. - 1982. Origin, age and evolution of Antarctic and deep-sea faunas. In: W.G. Ernst and J.G. Morin (eds.), The environment of the deep sea, pp. 324-356. Prentice Hall, Englewood Cliffs, New Jersey.

Lipps J.H., T.E. Ronan Jr. and T.E. De Laca. - 1979. Live below the Ross Sea Ice Shelf, Antarctica. Science, 203: 447-449.
Lomakina, N.S. - 1968. Cumacea of the Antarctic region. (From materials collected by the Soviet Antarctic Expedition of 19561958 and 1963). Issl. Fauny Morei, 6(14): 97-140. Translated into English by the Israel Program for Scientific Translations, Jerusalem 1970

Macquart-Moulin, C. - 1991. La phase pélagique nocturne des Cumacés. J Plankton Res., 13: 313-337.

Mees, J. and M.B. Jones. - 1997. The hyperbenthos. Oceanogr. Mar. Biol. Ann. Rev., 35: 221-255.

Mühlenhardt-Siegel, U. - 1994. Leucon parasiphonatus, a new species (Crustacea: Cumacea: Leuconidae) from Antarctic waters. Helgoländer Meeresunters., 48: 79-88.

Mühlenhardt-Siegel, U. - 1996. Some remarks on the taxonomy of Antarctic Leuconidae (Cumacea: Crustacea) with a description of a new species Leucon intermedius $\mathrm{n}$. sp. Helgolander Meeresunters., 50: 391-408.

Reyss, D. - 1973. Distribution of Cumacea in the deep Mediterranean. Deep Sea Res., 20: 1119-1123.

Roccatagliata, D. and R.W. Heard. - 1992. Diastylopsis goekei, a new species (Crustacea: Diastylidae) from Antarctic waters. Proc. Biol. Soc. Wash., 105: 743-752.

Sainte-Marie, B. and P. Brunel. - 1985. Suprabenthic gradients of swimming activity by cold-water gammaridean amphipod Crustacea over muddy shelf in the Gulf of Saint Lawrence. Mar. Ecol. Prog. Ser., 23: 57-69.

San Vicente, C., A. Ramos, A. Jimeno and J.-C. Sorbe. - 1997. Suprabenthic assemblages from South Shetland Islands and Bransfield Strait (Antarctica): preliminary observations on faunistical composition, bathymetric and near-bottom distribution. Polar Biol., 18: 415-422.

Sars, G.O. - 1887. Report on the Cumacea collected by H.M.S Challenger during the years 1873-76. Voyage of H.M.S. Challenger. Zoology 19(55): 1-78.

Sieg, J. - 1988. Das phylogenetische System der Tanaidacea und die frage nach alterund herkunft der Cruataceenfauna des antarktischen festlandsockels. Z. Zool. Syst. Evol. Forsch., 26: 363-379.

Siegel, V. and U. Mühlenhardt-Siegel . - 1988. On the occurrence and biology of some Antarctic Mysidacea (Crustacea). Polar Biol., 8: 181-190.

Wilson, G.D.F. and R.R. Hessler. - 1987. Speciation in the deep sea. Ann. Rev. Ecol. Syst., 18: 185-207.

Watling, L. and M.H. Thurston. - 1989. Antarctica as an evolutionary incubator: evidence from the cladistic biogeography of the amphipod Family Iphimediidae. In: J.A. Crame (ed.) Origins and evolution of Antarctic biota, pp. 297-313. Geological Society Special Publications, 47. London.

Zimmer, C. - 1907. Neue Cumaceen von der Deutschen und Schwedischen Südpolar-Expedition aus Familien der Cumiden, Vaunthompsoniiden, Nannastaciden und Lampropiden. Zool. Anz., 31(11-12): 367-374.

Zimmer, C. - 1908. Die Cumaceen der Deutschen Tiefsee-Expedition. Wiss. Ergeb. Deuts. Tiefsee-Exped. auf dem Dampfer Valdivia 1898-1899, 8: 155-196.

Zimmer, C. - 1909. Die Cumaceen der Schwedischen Südpolarexpedition 1901-1903. Wiss. Ergeb. Schwed. Südpolar- Exp. 1901-1903, 6: 437-492.

Zimmer, C. - 1913. Die Cumaceen der Deutchen Südpolar-Expedition 1901-03. Deutsche Südpol.-Exped. (1901-1903), 14(6): 437-491.

Zimmer, C. - 1920. Mittheilungen über Cumaceen des Berliner zoologischen Museums. Mitt. zool. Mus. Berlin, 10: 117-149.

Scient. ed.: J.D. Ros 